Review

\title{
Face Recognition as a Biometric Application
}

\author{
Relly Victoria Virgil Petrescu \\ ARoTMM-IFToMM, Bucharest Polytechnic University, Bucharest (CE), Romania
}

Article history

Received: 22-04-2019

Revised: 07-05-2019

Accepted: 13-05-2019

Corresponding Author: Relly Victoria Virgil Petrescu ARoTMM-IFToMM, Bucharest Polytechnic University, Bucharest, (CE), Romania E-mail: rvvpetrescu@gmail.com

\begin{abstract}
A facial recognition system is a technology capable of identifying or verifying a person from a digital image or a video frame from a video source. There are multiple methods in which facial recognition systems work, but in general, they work by comparing selected facial features from the given image with faces within a database. It is also described as a Biometric Artificial Intelligence-based application that can uniquely identify a person by analyzing patterns based on the person's facial textures and shape. While initially a form of computer application, it has seen wider uses in recent times on mobile platforms and in other forms of technology, such as robotics. It is typically used as access control in security systems and can be compared to other biometrics such as fingerprint or eye iris recognition systems. Although the accuracy of facial recognition system as biometric technology is lower than iris recognition and fingerprint recognition, it is widely adopted due to its contactless and noninvasive process. Recently, it has also become popular as a commercial identification and marketing tool. Other applications include advanced humancomputer interaction, video surveillance, automatic indexing of images and video database, among others. The use of facial recognition has recently become a very debatable subject and has been criticized more and more because it was considered an unethical tool used to spy on the public. The reason for such criticism is, however, largely due to the lack of information and regulation of this technology. Used proportionally and responsibly, facial recognition can and should be beneficial. It has the capacity to do much more to increase security in the future-from street crime to airport security. Armed war crime has dominated UK titles throughout the year. Recent statistics indicate that the number of people who benefited from the emergency assistance due to armed attacks increased by almost $40 \%$ compared to the two years ago, while the number of children under 18 years of age with stab wounds is increasing by $86 \%$ in only four years. Face recognition has become a normal activity in many airports around the world. Many people today have a so-called biometric passport that allows them to go faster to the gate without having to be controlled. The facial recognition used in this way has significantly reduced waiting times for passport control but also has the ability to increase security in and around airports. Face recognition thus allows officers to identify an individual more quickly and accurately than the human eye. While some critics may worry about technology-related confidentiality issues, airports have shown that the use of facial recognition has improved security as well as speeding up processes such as check-in and in the future, even procedures boarding. When used correctly and proportionally, facial recognition can help protect the public and improve national security on multiple fronts. Similarly, advanced technology can recognize a person seen on CCTV security systems at the crime scene, justifying a person's stop and search. The ability to check in real time whether a person is on the list of criminal investigations adds an added advantage to the decision-making process before stopping and searching, thus lowering the probability of discrimination.
\end{abstract}

Keywords: Biometrics, Robots, Mechatronic Systems, Facial Recognition, Facial Recognition System, IDENTIFYING a Person 


\section{Introduction}

The use of facial recognition has recently become a very debatable subject and has been criticized more and more because it was considered an unethical tool used to spy on the public. The reason for such criticism is, however, largely due to the lack of information and regulation of this technology. Used proportionally and responsibly, facial recognition can and should be beneficial. It has the capacity to do much more to increase security in the future-from street crime to airport security. Armed war crime has dominated UK titles throughout the year. Recent statistics indicate that the number of people who benefited from the emergency assistance due to armed attacks increased by almost $40 \%$ compared to the two years ago, while the number of children under 18 years of age with stab wounds is increasing by $86 \%$ in only four years.

This recent increase in crime has put the police forces under enormous pressure and the smart use of facial recognition has an increasingly important role.

\section{Facial Recognition in Criminal Investigations}

Here facial recognition can provide additional information. These systems can save the faces of suspects, gangs, wanted criminals and those suspected of involvement in serious violent crimes. Moreover, these systems do not require prior personal involvement to recognize an individual and only see data, not sex, age or race.

The technology does not decide instead of the cop. However, it provides greater transparency in the decision-making process on the opportunity to stop and searches intervention.

Similarly, advanced technology can recognize a person seen on CCTV security systems at the crime scene, justifying a person's stop and search.

The ability to check in real time whether a person is on the list of criminal investigations adds an added advantage to the decision-making process before stopping and searching, thus lowering the probability of discrimination. Face recognition helps eliminate guns and criminals on the streets and eventually prevent offenses before they have the chance to take place.

\section{Gambling Addiction and the Way Your Face Recognition Can Help}

There are an estimated 593,000 people in the UK who are currently struggling with a gambling problem, becoming a serious issue. Having grasped the seriousness of the problem, the British Gaming Commission set limits and tips to help those who suffer from this addiction; however, as with all addictions, gambling is a habit to overcome. In order to put real limits and make a real difference, the gambling commission needs the right technology.
Face recognition technology is capable of keeping track of players and thus helping gambling companies protect their customers to a higher degree. Monitoring who enters and moves around gambling areas is an extremely difficult task for the human staff, especially in crowded areas such as casinos.

In-Face Face Recognition Technology could help the company and staff identify who registered as gambling addicts and keep track of daily play to inform staff if and when it is time to stop. It would also be able to provide effective self-exclusion procedures by identifying an individual exclusively through CCTV security systems as soon as they entered the location to allow security staff to escort them with respect.

\section{Face Recognition in Airport Security}

Face recognition has become a normal activity in many airports around the world. Many people today have a so-called biometric passport that allows them to go faster to the gate without having to be controlled. The facial recognition used in this way has significantly reduced waiting times for passport control but also has the ability to increase security in and around airports. Face recognition thus allows officers to identify an individual more quickly and accurately than the human eye.

While some critics may worry about technologyrelated confidentiality issues, airports have shown that the use of facial recognition has improved security as well as speeding up processes such as check-in and in the future, even procedures boarding.

When used correctly and proportionally, facial recognition can help protect the public and improve national security on multiple fronts.

Pioneers of automatic face recognition include Woody Bledsoe, Helen Chan Wolf and Charles Bisson.

In 1964 and 1965, Bledsoe together with Helen Chan and Charles Bisson worked on using the computer to recognize human faces. He was proud of this work, but because the funding was provided by an unnamed computer agency that did not allow too much advertising, few papers were published. Based on the available references, it was found that Bledsoe's initial approach involves the manual marketing of various facets, such as eye centers, mouths, etc., mathematically matched to offset possible variations. The distances between the landmarks were also automatically calculated and compared between the images to determine the identity.

Considering a wide range of images (in fact, a photo card) and a photo, the problem was to select from a database a small set of recordings, so one of the recorded images corresponds to the photo. The success of the method can be measured by the ratio of the response list and the number of records in the database. Bledsoe (1966a) described the following difficulties: 
"This recognition problem is difficult due to the high variability of inclination and head inclination, illumination and angle, face expression, aging, etc. Some other face recognition tests by the machine have allowed little or no variability in these values, the variability is large, the correlation is very small between two images of the same person, two different rotations of the head.

\section{Woody Bledsoe, 1966}

This project was labeled man-machine because man extracted the coordinates of a set of features in photos, which were then used by the computer for recognition. Using a graphics tablet (GRAFACON or RAND TABLET), the operator would extract the coordinates of the elements, such as the pupils' center, the inner corner of the eyes, the outer corner of the eye, the widow's point and soon. From these coordinates, a list of 20 distances, such as the width of the mouth and the width of the eyes, the pupil's student, was calculated. These operators could process about 40 photos per hour. When building the database, the name of the person in the photo was associated with the calculated distance list stored in the computer. In the recognition phase, the distance set was compared to the corresponding distance for each photograph, resulting in a distance between the photograph and the database recording. The closest records are returned.

Since two images are unlikely to match head rotation, tilting, tilting and scale (distance from the camera), each set of distances is normalized to represent the face in a front orientation. To achieve this normalization, the program first attempts to determine the inclination, the poor and the rotation. Then, using these angles, the computer cancels the effect of these transformations on the calculated distances. To calculate these angles, the computer must know the three-dimensional head geometry. Because there were no real heads, Bledsoe (1964) used a standard head obtained from seven-headed measurements.

After Bledsoe left the PRI in 1966, this work was continued at the Stanford Research Institute, primarily by Peter Hart. In experiments on a database of more than 2000 photos, the computer has constantly exceeded people when it presented the same recognition tasks (Bledsoe 1968). Peter Hart (1996) enthusiastically recalled the project with the exclamation "It was really a work!"

Around 1997, the system developed by Christoph von der Malsburg and graduate students of the University of Bochum in Germany and the University of Southern California in the United States has outstripped most systems with those of the Massachusetts Institute of Technology and the University of Maryland. The Bochum system was developed with funding from the
US Army Research Laboratory. The software was sold as ZN-Face and used by customers such as Deutsche Bank and airport operators and other crowded locations. The software was "robust enough to make face-to-face identification less than perfect." Such impediments that identify themselves as mosquitoes, beards, changed hairstyles and glasses-even sunglasses (Rulkov et al., 2016; Agarwala, 2016; Babayemi, 2016; Gusti and Semin, 2016; Mohamed et al., 2016; Wessels and Raad, 2016; Maraveas et al., 2015; Khalil, 2015; RhodeBarbarigos et al., 2015; Takeuchi et al., 2015; Li et al., 2015; Vernardos and Gantes, 2015; Bourahla and Blakeborough, 2015; Stavridou et al., 2015a; Ong et al., 2015; Dixit and Pal, 2015; Rajput et al., 2016; Rea and Ottaviano, 2016; Zurfi and Zhang, 2016 a-b; Zheng and Li, 2016; Yang, and Lin, 2015; Buonomano et al., 2016 a-b; Faizal et al., 2016; Cataldo, 2006; Ascione et al., 2016; Elmeddahi et al., 2016; Calise et al., 2016; Morse et al., 2016; Abouobaida, 2016; Rohit and Dixit, 2016; Kazakov et al., 2016; Alwetaishi, 2016; Riccio et al., 2016 a-b; Iqbal, 2016; Hasan and El-Naas, 2016; AlHasan and Al-Ghamdi, 2016; Jiang et al., 2016; Sepúlveda, 2016; Martins et al., 2016; Pisello et al., 2016; Jarahi, 2016; Mondal et al., 2016; Mansour, 2016; Al Qadi et al., 2016b; Campo et al., 2016; Samantaray et al., 2016; Malomar et al., 2016; Rich and Badar, 2016; Hirun, 2016; Bucinell, 2016; Nabilou, 2016b; Barone et al., 2016; Chisari and Bedon, 2016; Bedon and Louter, 2016; Santos and Bedon, 2016; Minghini et al., 2016; Bedon, 2016; Jafari et al., 2016; Chiozzi et al., 2016; Orlando and Benvenuti, 2016; Wang and Yagi, 2016; Obaiys et al., 2016; Ahmed et al., 2016; Jauhari et al., 2016; Syahrullah and Sinaga, 2016; Shanmugam, 2016; Jaber and Bicker, 2016; Wang et al., 2016; Moubarek and Gharsallah, 2016; Amani, 2016; Shruti, 2016; Pérezde León et al., 2016; Mohseni and Tsavdaridis, 2016; Abu-Lebdeh et al., 2016; Serebrennikov et al., 2016; Budak et al., 2016; Augustine et al., 2016; Jarahi and Seifilaleh, 2016; Nabilou, 2016a; You et al., 2016; AL Qadi et al., 2016a; Rama et al., 2016; Sallami et al., 2016; Huang et al., 2016; Ali et al., 2016; Kamble and Kumar, 2016; Saikia and Karak, 2016; Zeferino et al., 2016; Pravettoni et al., 2016; Bedon and Amadio, 2016; Chen and $\mathrm{Xu}, 2016$; Mavukkandy et al., 2016; Gruener, 2006; Yeargin et al., 2016; Madani and Dababneh, 2016; Alhasanat et al., 2016; Elliott et al., 2016; Suarez et al., 2016; Kuli et al., 2016; Waters et al., 2016; Montgomery et al., 2016; Lamarre et al., 2016; Daud et al., 2008; Taher et al., 2008; Zulkifli et al., 2008; Pourmahmoud, 2008; Pannirselvam et al., 2008; Ng et al., 2008; ElTous, 2008; Akhesmeh et al., 2008; Nachiengtai et al., 2008; Moezi et al., 2008; Boucetta, 2008; Darabi et al., 2008; Semin and Bakar, 2008; Al-Abbas, 2009; Abdullah et al., 2009; Abu-Ein, 2009; Opafunso et al., 2009; Semin et al., 2009 a-c; Zulkifli et al., 2009; Marzuki et al., 2015; Bier and Mostafavi, 2015; Momta et al., 2015; Farokhi 
and Gordini, 2015; Khalifa et al., 2015; Yang and Lin, 2015; Chang et al., 2015; Demetriou et al., 2015; Rajupillai et al., 2015; Sylvester et al., 2015a; Ab-Rahman et al., 2009; Abdullah and Halim, 2009; Zotos and Costopoulos, 2009; Feraga et al., 2009; Bakar et al., 2009; Cardu et al., 2009; Bolonkin, 2009 a-b; Nandhakumar et al., 2009; Odeh et al., 2009; Lubis et al., 2009; Fathallah and Bakar, 2009; Marghany and Hashim, 2009; Kwon et al., 2010; Aly and Abuelnasr, 2010; Farahani et al., 2010; Ahmed et al., 2010; Kunanoppadon, 2010; Helmy and El-Taweel, 2010; Qutbodin, 2010; Pattanasethanon, 2010; Fen et al., 2011; Thongwan et al., 2011; Theansuwan and Triratanasirichai, 2011; Al Smadi, 2011; Tourab et al., 2011; Raptis et al., 2011; Momani et al., 2011; Ismail et al., 2011; Anizan et al., 2011; Tsolakis and Raptis, 2011; Abdullah et al., 2011; Kechiche et al., 2011; Ho et al., 2011; Rajbhandari et al., 2011; Aleksic and Lovric, 2011; Kaewnai and Wongwises, 2011; Idarwazeh, 2011; Ebrahim et al., 2012; Abdelkrim et al., 2012; Mohan et al., 2012; Abam et al., 2012; Hassan et al., 2012; Jalil and Sampe, 2013; Jaoude and El-Tawil, 2013; Ali and Shumaker, 2013; Zhao, 2013; El-Labban et al., 2013; Djalel et al., 2013; Nahas and Kozaitis, 2013; Petrescu and Petrescu, 2014 a-i, 2015 a-e, 2016 a-d; Fu et al., 2015; Al-Nasra et al., 2015; Amer et al., 2015; Sylvester et al., 2015b; Kumar et al., 2015; Gupta et al., 2015; Stavridou et al., 2015b; Casadei, 2015; Ge and Xu, 2015; Moretti, 2015; Wang et al., 2015; Antonescu and Petrescu, 1985; 1989; Antonescu et al., 1985a; 1985b; 1986; 1987; 1988; 1994; 1997; 2000a; 2000b; 2001; Aversa et al., 2017a; 2017b; 2017c; 2017d; 2017e; 2016a; 2016b; 2016c; 2016d; 2016e; 2016f; 2016g; 2016h; 2016i; 2016j; 2016k; 2016l; 2016m; 2016n; 2016o; Cao et al., 2013; Dong et al., 2013; Comanescu, 2010; Franklin, 1930; He et al., 2013; Padula and Perdereau, 2013; Perumaal and Jawahar, 2013; Petrescu, 2011; 2015a; 2015b; Petrescu and Petrescu, 1995a; 1995b; 1997a; 1997b; 1997c; 2000a; 2000b; $2002 \mathrm{a} ; 2002 \mathrm{~b} ; 2003$; 2005a; 2005b; 2005c; 2005d; 2005e; 2011a; 2011b; 2012a; 2012b; 2013a; 2013b; 2013c; 2013d; 2013e; 2016a; 2016b; 2016c; Petrescu et al., 2009; 2016; 2017a; 2017b; 2017c; 2017d; 2017e; 2017f; 2017g; 2017h; 2017i; 2017j; 2017k; 2017l; 2017m; 2017n; 2017o; 2017p; 2017q; 2017r; 2017s; 2017t; 2017u; 2017v; 2017w; 2017x; 2017y; 2017z; 2017aa; 2017ab; 2017ac; 2017ad; 2017ae; 2018a; 2018b; 2018c; 2018d; 2018e; 2018f; 2018g; 2018h; 2018i; 2018j; 2018k; 20181; 2018m; 2018n).

\section{Materials and Methods}

In 2006, the performance of the latest face recognition algorithms was evaluated in the Grand Challenge Face Recognition (FRGC). High-resolution images, 3D-face scans and iris images were used in tests. The results have shown that the new algorithms are 10 times more accurate than face recognition algorithms in 2002 and 100 times more accurate than those in 1995. Some of the algorithms have succeeded in overcoming human performance in face recognition and unique identification of identical twins.

The US Government sponsored evaluations and provocative issues have stimulated two-dimensional orders in the face recognition system. Since 1993, the error rate of automatic face recognition systems has fallen by a factor of 272 . The reduction applies to systems that fit people with face-images captured in studio or mugshot environments. As for Moore's law, the error rate has fallen by half every two years.

Low-resolution faces can be improved by hallucinations of the face.

Essentially, face recognition is done in two stages. The first involves extracting and selecting features and the second is the classification of objects. Subsequently, developments have introduced different technologies in the procedure. Some of the most notable include the following techniques.

\section{Traditional}

Certain face recognition algorithms identify facial features by extracting markers or features from a face-toface image. For example, an algorithm can analyze the position, size and/or relative shape of the eyes, nose, cheekbones and jaw. These features are then used to look for other matching features.

Other algorithms normalize a gallery of images and compress the face data, saving only image data that is useful for face recognition. A probe image is then compared to face data. One of the oldest successful systems is based on model matching techniques applied to a set of special facial features, offering a kind of tablet representation.

Recognition algorithms can be divided into two main geometric approaches that refer to distinctive or photometric features, representing a statistical approach that distills a picture in values and compares values with patterns to eliminate variants. Some classify these algorithms in two broad categories: holistic and feature-based models. The first attempts to fully recognize the face, while the function is based on a subdivision into components, such as according to the characteristics and each analysis and its spatial location relative to other characteristics.

Popular recognition algorithms include the main component analysis using eigenfaces, linear differential analysis, elastic graphics matching using the fisher face algorithm, the Markov hidden pattern, multiple subspace learning using tensor representation and dynamic matching of neural motifs.

\section{Dimensional Recognition}

Three-dimensional face recognition technology uses $3 \mathrm{D}$ sensors to capture information about the shape of a 
face. This information is then used to identify distinctive features on the surface of a face, such as the outline of the eye, nose and chin sockets.

An advantage of 3D Face Recognition is that it is not affected by changes in lighting as well as by other techniques. It can also identify a face in a series of viewing angles, including a profile view. Threedimensional images on one side significantly improve the accuracy of face recognition. 3D research is enhanced by developing sophisticated sensors that make a better job of capturing 3D images. The sensors work by projecting structured light on the front. Up to a dozen or more of this image, the sensors can be placed on the same CMOS chip-each sensor captures another part of the spectrum.

Even a perfect 3D matching technique could be sensitive to phrases. To this end, a Technion group applied metric geometric instruments to treat expressions such as isometries.

A new method is to introduce a way to capture a $3 \mathrm{D}$ image using three tracking chambers that indicate different angles; a single camera will be directed to the front of the subject, aside second and the third under an angle. All these cameras will work together so they can track the subject's face in real time and be able to face detection and recognition.

\section{Skin Texture Analysis}

Another emerging trend uses the visual details of the skin as captured in standard or scanned digital images. This technique, called Skin Texture Analysis, transforms lines, patterns and unique stains into a person's skin in a mathematical space.

Surface texture analysis works just like facial recognition. It is made of a leather patch, called skin print. This patch is then divided into smaller blocks. Using algorithms to transform the patch into a measurable mathematical space, the system will then distinguish the lines, pores and real skin texture. It can identify the contrast between identical pairs, which are not yet possible using facial recognition software alone.

Tests have shown that by adding a skin texture analysis, performance in girls' recognition can increase by $20-25 \%$.

\section{Physical Recognition by Combining Different Techniques}

Because each method has its advantages and disadvantages, technology companies have combined traditional, 3D and skin text analysis to create recognition systems that have higher success rates.

Combined techniques have an advantage over other systems. It is relatively insensitive to changing expression, including blinking, frowning or smiling and having the ability to compensate for the growth of mustache or beard and the appearance of glasses. The system is also uniform in terms of race and gender.

\section{Thermal Rooms}

Another form of face recognition is the use of thermal cameras, this camera will only detect the head shape and will ignore subjects such as glasses, hats or makeup. Unlike conventional cameras, thermal cameras can capture images even in low light and night conditions without using the flash and exposure to the camera's position. However, a problem with the use of thermal imaging for face recognition is that the face recognition bases are limited. Diego Socolinsky and Andrea Selinger (2004) investigate the use of face thermo recognition in life and operating scenes and at the same time build a new thermal imaging database. The study uses sensors with low sensitivity, low sensitivity, low sensitivity, low sensitivity (F), capable of acquiring Long Infrared Thermoelectric (LWIR) thermoelectric sensors. The results show that a fusion of LWIR chambers and common visual cameras has better outcomes on outside probes. The results from the inside show that the vision has an accuracy of $97.05 \%$, while LWIR has $93.93 \%$ and Fusion is $98.40 \%$, however, $67.06 \%$ on the outside, LWIR $83.03 \%$ and $89.02 \%$ merger. The study used 240 subjects over a 10 -week period to create a new database. The data were collected on sunny, rainy and cloudy days.

In 2018, researchers at the American Army Research Laboratory (ARL) have developed a technique that will allow them to fit facial images obtained using a thermal camera with those in databases that were captured using a conventional camera. This approach has used artificial intelligence and machine learning to allow researchers to compare thermal and regular face images. Known in the form of a cross-stitch method, because of how it covers facial recognition from two different imaging modalities, this method synthesizes a single image by analyzing multiple regions and face details. It is comprised of a nonlinear regression model that maps a specific thermal image into a corresponding facial image and an optimization problem that projects the latent projection back into the image space.

ARL researchers have noticed that the approach works by combining global information (e.g., face-toface) with local information (e.g., eye, nose and mouth). In addition to increasing the discrimination of the synthesized image, the facial recognition system can be used to transform the signature of a thermal face into a visible face image. According to ARL performance tests, the researchers found that the multi-region synthesis model demonstrated an improvement in the performance of about $30 \%$ over base methods and about $5 \%$ over the latest generation. It has also been tested for real-time thermal imaging. 


\section{Results and Discussion}

\section{Mobile Platforms}

\section{Social Media}

Social media platforms have embraced facial recognition capabilities to diversify their functionality to attract a wider user base to rigid competition from different applications.

Founded in 2013, Looksery continued to raise money for Kickstarter Face Editing. Following the success of the general public, Looksery launched in October 2014. The application allows video chatting with others through a special face-changing filter that changes the look of users. While there are image enhancement applications such as FaceTune and Perfect365, they are limited to static images, while Looksery has allowed augmented reality to see videos. At the end of 2015, SnapChat acquired Looksery, which was to become the function of its goal.

SnapChat's animated targets, which use face recognition technology, revolutionize and redefine automatically, allowing users to add filters to change their look. Filtering daily filtering selections, some examples include one that makes users look like an old version of them, one that blows up the skin and one that puts a virtual flower ring on their heads. Dog Filter is the most popular filter that helped SnapChat succeed, with celebrities are known as Gigi Hadid, Kim Kardashian and regularly likes to post dogs with the dog filter.

DeepFace is a deep learning facial recognition system created by a Facebook research group.

\section{Identifies Human Faces in Digital Images}

It uses a nine-layer neural network with over 120 million connection weights and has been trained on four million images uploaded by Facebook users. It is said that the system is $97 \%$ correct, compared to $85 \%$ for the FBI system to identify future generations. One of the software developers, Yaniv Taigman, has come facebook with facebook.

The emerging use of facial recognition is the use of identity verification services. Many companies are now working on the market to provide these services to banks, ICOs and other electronic companies.

Apple introduced the iPhone X ID as the successor of biometric authentication to Touch ID, a fingerprint system. The face ID has a face recognition sensor, consisting of two parts: a "Romeo" module projecting over 30,000 infrared points on the user's face and a "Julie" module reading the model. The model is sent to a local "Secure Enclave" from the device's Central Processing Unit (CPU) to confirm a match with the owner of the phone. The facial model is not accessible to Apple. The system will not work with eyes closed in an attempt to prevent unauthorized access.
The technology learns from changes in the appearance of a user and therefore works with hats, scarves, glasses and many sunglasses, beards and makeup.

It also works in the dark. This is done using a "flood illuminator," which is a dedicated infrared light that throws invisible infrared light on the user's face to read 30,000 facial points properly.

\section{Police}

The Australian Border Service and New Zealand have created an automated border processing system called SmartGate, which uses face recognition, which compares the passenger's face with the e-passport microchip data. All Canadian international airports use Face Recognition as part of the Primary Inspection Kiosk program that compares a person traveling with the photo stored on ePassport. This program first came to Vancouver International Airport in early 2017 and was launched at all international airports remaining in 20182019. "Tocumen International Airport" in Panama operates an airport-based surveillance system that uses hundreds of live face recognition rooms to identify people who pass through the airport

British police companies are sending face recognition technology to public events in 2015. However, a recent report and an investigation by Big Brother Watch showed that these systems were up to $98 \%$ inaccurate

The US State Department manages one of the largest face recognition systems in the world, with an adult database of 117 million adults, usually taken from driving licenses. Although it is still far from being completed, it is implemented in some cities to give clues about who was in the photo. The FBI uses the photos as a tool.

In addition to being used for security systems, authorities have found a number of other applications for face recognition systems. Although previous post-9/11 implementations have been well publicized, more recent developments are rarely written due to their undercover nature.

At the Super Bowl XXXV in January 2001, Tampa Bay, the Florida police used the Visage Face Recognition program to search for potential offenders and terrorists to attend the event. 19 persons with a minor criminal record were potentially identified.

In the 2000 Mexican presidential election, the Mexican government used face recognition software to prevent electoral fraud. Some voted under several different names in an attempt to cast more votes. By comparing new images with those already in the voter database, the authorities have succeeded in reducing duplicate records. Similar technologies are used in the United States to prevent people from obtaining false identification cards and driving licenses 
Face recognition has been used as a form of biometric authentication for different platforms and computing devices; Android 4.0 Ice Cream Sandwich added facial recognition using the front of the smartphone as a means to unlock devices, while Microsoft introduced face recognition authentication on the Xbox 360 video game console via the Kinect accessory and the Windows 10 platform in infrared products. Uses an infrared illumination system.

Face recognition systems have also been used by photo management software to identify photo subjects, enabling features such as searching for personal images as well as suggesting photos to be shared with a specific contact if the presence theirs was detected in a photo.

Face recognition is used as security added to certain sites, phone applications and payment methods.

Taylor Swift, a popular musician and popular musician in the United States, secretly uses face recognition technology at a concert in 2018. The device was embedded in a kiosk next to a ticket box and was scanned by concerts over time, met with the pursuers.

A key advantage of a face recognition system that it can identify by mass because it does not require the cooperation test. Well-designed systems installed at airports, multiplexes and other public places can identify people among fleets, even if they are aware of the system.

However, compared to other biometric techniques, face recognition may not be the most reliable and effective. Quality measures are very important in facial recognition systems, as there are large variations in these images. Factors such as illumination, expression, image and noise during face capture can affect the performance of facial recognition systems. Of all biometric systems, facial recognition has the highest rates of false acceptance and rejection, so questions have arisen about the effectiveness of facial recognition software in railway safety and at airports.

Ralph Gross, a researcher at the Robotics Institute Carnegie Mellon in 2008, describes a hindrance to visualization: "Face recognition has become pretty good in the face and 20 degrees, but once you get to profile, there have been problems." In addition to possible variants, high-resolution images are also very difficult to recognize. This is one of the main obstacles to recognition in supervisory systems.

Face recognition is less effective if face expression varies. A big smile can make the system less efficient. For example, Canada, in 2009, allowed only neutral facial expressions in passport photos.

There is also an inconsistency in the datasets used by researchers. Researchers can use anywhere from multiple topics to dozens of topics and hundreds of images to thousands of images. It is important for researchers to make available data sets that have used each other or have at least one standard data set.

Privacy is the primary concern for the storage of biometric data in companies. Chip or storage of biometric data can be accessed by a third party if it is not stored or hacked properly. In Techworld, Parris adds (2017) that "hackers will already be looking to reproduce their faces.

\section{Conclusion}

The use of facial recognition has recently become a very debatable subject and has been criticized more and more because it was considered an unethical tool used to spy on the public. The reason for such criticism is, however, largely due to the lack of information and regulation of this technology. Used proportionally and responsibly, facial recognition can and should be beneficial. It has the capacity to do much more to increase security in the future - from street crime to airport security. Armed war crime has dominated UK titles throughout the year. Recent statistics indicate that the number of people who benefited from the emergency assistance due to armed attacks increased by almost $40 \%$ compared to the two years ago, while the number of children under 18 years of age with stab wounds is increasing by $86 \%$ in only four years.

This recent increase in crime has put the police forces under enormous pressure and the smart use of facial recognition has an increasingly important role.

\section{Facial Recognition in Criminal Investigations}

Here facial recognition can provide additional information. These systems can save the faces of suspects, gangs, wanted criminals and those suspected of involvement in serious violent crimes. Moreover, these systems do not require prior personal involvement to recognize an individual and only see data, not sex, age or race.

The technology does not decide instead of the cop. However, it provides greater transparency in the decision-making process on the opportunity to stop and searches intervention.

Similarly, advanced technology can recognize a person seen on CCTV security systems at the crime scene, justifying a person's stop and search.

The ability to check in real time whether a person is on the list of criminal investigations adds an added advantage to the decision-making process before stopping and searching, thus lowering the probability of discrimination. Face recognition helps eliminate guns and criminals on the streets and eventually prevent offenses before they have the chance to take place.

\section{Gambling Addiction and the Way Your Face Recognition Can Help}

There are an estimated 593,000 people in the UK who are currently struggling with a gambling problem, becoming a serious issue. Having grasped the seriousness of 
the problem, the British Gaming Commission set limits and tips to help those who suffer from this addiction; however, as with all addictions, gambling is a habit to overcome. In order to put real limits and make a real difference, the gambling commission needs the right technology.

Face recognition technology is capable of keeping track of players and thus helping gambling companies protect their customers to a higher degree. Monitoring who enters and moves around gambling areas is an extremely difficult task for the human staff, especially in crowded areas such as casinos.

In-Face Face Recognition Technology could help the company and staff identify who registered as gambling addicts and keep track of daily play to inform staff if and when it is time to stop. It would also be able to provide effective self-exclusion procedures by identifying an individual exclusively through CCTV security systems as soon as they entered the location to allow security staff to escort them with respect.

\section{Face Recognition in Airport Security}

Face recognition has become a normal activity in many airports around the world. Many people today have a so-called biometric passport that allows them to go faster to the gate without having to be controlled. The facial recognition used in this way has significantly reduced waiting times for passport control but also has the ability to increase security in and around airports. Face recognition thus allows officers to identify an individual more quickly and accurately than the human eye.

While some critics may worry about technologyrelated confidentiality issues, airports have shown that the use of facial recognition has improved security as well as speeding up processes such as check-in and in the future, even procedures boarding.

When used correctly and proportionally, facial recognition can help protect the public and improve national security on multiple fronts.

\section{Acknowledgement}

This text was acknowledged and appreciated by Dr. Veturia CHIROIU Honorific member of Technical Sciences Academy of Romania (ASTR) PhD supervisor in Mechanical Engineering.

\section{Funding Information}

Research contract: 1-Research contract: Contract number 36-5-4D/1986 from 24IV1985, beneficiary CNST RO (Romanian National Center for Science and Technology) Improving dynamic mechanisms.

2-Contract research integration. 19-91-3 from 29.03.1991; Beneficiary: MIS; TOPIC: Research on designing mechanisms with bars, cams and gears, with application in industrial robots.
3-Contract research. GR 69/10.05.2007: NURC in 2762; theme 8: Dynamic analysis of mechanisms and manipulators with bars and gears.

4-Labor contract, no. 35/22.01.2013, the UPB, "Stand for reading performance parameters of kinematics and dynamic mechanisms, using inductive and incremental encoders, to a Mitsubishi Mechatronic System" "PN-IIIN-CI-2012-1-0389".

All these matters are copyrighted! Copyrights: 394qodGnhhtej, from 17-02-2010 13:42:18; 463vpstuCGsiy, from 20-03-2010 12:45:30; 631sqfsgqvutm, from 24-05-2010 16:15:22; 933CrDztEfqow, from 07-01-2011 13:37:52.

\section{Ethics}

This article is original and contains unpublished material. Authors declare that are not ethical issues and no conflict of interest that may arise after the publication of this manuscript.

\section{References}

Ab-Rahman, M.S., H. Guna, M.H. Harun, S.D. Zan and K. Jumari, 2009. Cost-effective fabrication of selfmade $1 \times 12$ polymer optical fiber-based optical splitters for automotive application. Am. J. Eng. Applied Sci., 2: 252-259.

DOI: 10.3844/ajeassp.2009.252.259

Abam, F.I., I.U. Ugot and D.I. Igbong, 2012. Performance analysis and components irreversibilities of a $(25 \mathrm{MW})$ gas turbine power plant modeled with a spray cooler. Am. J. Eng. Applied Sci., 5: 35-41.

DOI: 10.3844/ajeassp.2012.35.41

Abdelkrim, H., S.B. Othman, A.K.B. Salem and S.B. Saoud, 2012. Dynamic partial reconfiguration contribution on system on programmable chip architecture for motor drive implementation. Am. J. Eng. Applied Sci., 5: 15-24.

DOI: 10.3844/ajeassp.2012.15.24

Abdullah, H. and S.A. Halim, 2009. Electrical and magnetoresistive studies $\mathrm{Nd}$ doped on La-Ba-MnO3 manganites for low-field sensor application. Am. J. Eng. Applied Sci., 2: 297-303. DOI: 10.3844/ajeassp.2009.297.303

Abdullah, M., A.F.M. Zain, Y.H. Ho and S. Abdullah, 2009. TEC and scintillation study of equatorial ionosphere: A month campaign over sipitang and Parit Raja stations, Malaysia. Am. J. Eng. Applied Sci., 2: 44-49. DOI: 10.3844/ajeassp.2009.44.49

Abdullah, M.Z. A. Saat and Z. Hamzah, 2011. Optimization of energy dispersive X-ray fluorescence spectrometer to analyze heavy metals in moss samples. Am. J. Eng. Applied Sci., 4: 355-362. DOI: 10.3844/ajeassp.2011.355.362 
Abouobaida, H., 2016. Robust and efficient controller to design a standalone source supplied DC and AC load powered by photovoltaic generator Am. J. Eng. Applied Sci., 9: 894-901.

DOI: 10.3844 /ajeassp.2016.894.901

Abu-Ein, S., 2009. Numerical and analytical study of exhaust gases flow in porous media with applications to diesel particulate filters. Am. J. Eng. Applied Sci., 2: 70-75. DOI: 10.3844/ajeassp.2009.70.75

Abu-Lebdeh, T.M., G. Pérez-de León, S.A. Hamoush, R.D. Seals and V.E. Lamberti, 2016. Gas atomization of molten metal: Part II. applications. Am. J. Eng. Applied Sci., 9: 334-349. DOI: 10.3844/ajeassp.2016.334.349

Agarwala, S., 2016. A perspective on 3D bioprinting technology: Present and future. Am. J. Eng. Applied Sci., 9: 985-990. DOI: 10.3844/ajeassp.2016.985.990

Ahmed, M., R. Khan, M. Billah and S. Farhana, 2010. A novel navigation algorithm for hexagonal hexapod robot. Am. J. Eng. Applied Sci., 3: 320-327. DOI: 10.3844/ajeassp.2010.320.327

Ahmed, R., M. Khan, H. Haque and H. Rahman, 2016. An approach to develop a dynamic job shop scheduling by fuzzy rule-based system and comparative study with the traditional priority rules. Am. J. Eng. Applied Sci., 9: 202-212. DOI: 10.3844/ajeassp.2016.202.212

Akhesmeh, S., N. Pourmahmoud and H. Sedgi, 2008. Numerical study of the temperature separation in the ranque-hilsch vortex tube. Am. J. Eng. Applied Sci., 1: 181-187. DOI: 10.3844/ajeassp.2008.181.187

AL Qadi, A.N.S., M.B.A. ALhasanat, A. AL Dahamsheh and S. AL Zaiydneen, 2016a. Using of box-benken method to predict the compressive strength of selfcompacting concrete containing wadi musa bentonite. Jordan. Am. J. Eng. Applied Sci., 9: 406-411. DOI: 10.3844/ajeassp.2016.406.411

Al Qadi, A.N.S., M.B.A. Alhasanat and M. Haddad, 2016b. Effect of crumb rubber as coarse and fine aggregates on the properties of asphalt concrete. Am. J. Eng. Applied Sci., 9: 558-564. DOI: 10.3844/ajeassp.2016.558.564

Al Smadi, T.A., 2011. Low cost smart sensor design. Am. J. Eng. Applied Sci., 4: 162-168. DOI: 10.3844/ajeassp.2011.162.168

Al-Abbas, I.K., 2009. Reduced order models of a current source inverter induction motor drive. Am. J. Eng. Applied Sci., 2: 39-43. DOI: 10.3844 /ajeassp.2009.39.43

Aleksic, S. and A. Lovric, 2011. Energy consumption and environmental implications of wired access networks. Am. J. Eng. Applied Sci., 4: 531-539. DOI: 10.3844/ajeassp.2011.531.539

Al-Hasan, M.I. and A.S. Al-Ghamdi, 2016. Energy balance for a diesel engine operates on a pure biodiesel, diesel fuel and biodiesel-diesel blends. Am. J. Eng. Applied Sci., 9: 458-465. DOI: 10.3844 /ajeassp.2016.458.465
Alhasanat, M.B., A.N. Al Qadi, O.A. Al Khashman and A. Dahamsheh, 2016. Scanning electron microscopic evaluation of self-compacting concrete spalling at elevated temperatures. Am. J. Eng. Applied Sci., 9: 119-127. DOI: 10.3844/ajeassp.2016.119.127

Ali, G.A.M., O. Fouad and S.A. Makhlouf, 2016. Electrical properties of cobalt oxide/silica nanocomposites obtained by sol-gel technique. Am. J. Eng. Applied Sci., 9: 12-16. DOI: 10.3844/ajeassp.2016.12.16

Ali, K.S. and J.L. Shumaker, 2013. Hardware in the loop simulator for multi-agent unmanned aerial vehicles environment. Am. J. Eng. Applied Sci., 6: 172-177. DOI: 10.3844/ajeassp.2013.172.177

Al-Nasra, M., M. Daoudb and T.M. Abu-Lebdeh, 2015. The use of the super absorbent polymer as water blocker in concrete structures. Am. J. Eng. Applied Sci., 8: 659-665. DOI: 10.3844/ajeassp.2015.659.665

Alwetaishi, M.S., 2016. Impact of building function on thermal comfort: A review paper. Am. J. Eng. Applied Sci., 9: 928-945. DOI: 10.3844/ajeassp.2016.928.945

Aly, W.M. and M.S. Abuelnasr, 2010. Electronic design automation using object oriented electronics. Am. J. Eng. Applied Sci., 3: 121-127. DOI: 10.3844/ajeassp.2010.121.127

Amani, N., 2016. Design and implementation of optimum management system using cost evaluation and financial analysis for prevention of building failure. Am. J. Eng. Applied Sci., 9: 281-296.

DOI: 10.3844/ajeassp.2016.281.296

Amer, S., S. Hamoush and T.M. Abu-Lebdeh, 2015. Experimental evaluation of the raking energy in damping system of steel stud partition walls. Am. J. Eng. Applied Sci., 8: 666-677.

DOI: 10.3844/ajeassp.2015.666.677

Angeles, J. and C. Lopez-Cajun, 1988. Optimal synthesis of cam mechanisms with oscillating flat-face followers. Mechanism Machine Theory, 23: 1-6. DOI: 10.1016/0094-114X(88)90002-X

Anizan, S., K. Yusri, C.S. Leong, N. Amin, S. Zaidi and K. Sopian, 2011. Effects of the contact resistivity variations of the screen-printed silicon solar cell. Am. J. Eng. Applied Sci., 4: 328-331. DOI: 10.3844/ajeassp.2011.328.331

Antonescu, P. and F.I.T. Petrescu, 1985. An analytical method of synthesis of cam mechanism and flat stick. Proceedings of the 4th International Symposium on Theory and Practice of Mechanisms, (TPM' 85), Bucharest.

Antonescu, P. and F.I.T. Petrescu, 1989. Contributions to cinetoelastodynamic analysis of distribution mechanisms. SYROM'89, Bucharest.

Antonescu, P., 2000. Mechanisms and Handlers. 1st Edn., Printech Publishing House, Bucharest. 
Antonescu, P., F. Petrescu and O. Antonescu, 2001. Contributions to the synthesis of mechanisms with rotary disc-cam. Proceedings of the 8th IFToMM International Symposium on Theory of Machines and Mechanisms, (TMM' 01), Bucharest, Romania, pp: 31-36.

Antonescu, P., F.I.T. Petrescu and D. Antonescu, 1997. Geometrical synthesis of the rotary cam and balance tappet mechanism. Bucharest, 3: 23-23.

Antonescu, P., F.I.T. Petrescu and O. Antonescu, 1994. Contributions to the synthesis of the rotating cam mechanism and the tip of the balancing tip. Brasov.

Antonescu, P., F.I.T. Petrescu and O. Antonescu, 2000a. Contributions to the synthesis of the rotary disc-cam profile. Proceedings of the 8th International Conference on the Theory of Machines and Mechanisms, (TMM' 00), Liberec, Czech Republic, pp: 51-56.

Antonescu, P., F.I.T. Petrescu and O. Antonescu, 2000b. Synthesis of the rotary cam profile with balance follower. Proceedings of the 8th Symposium on Mechanisms and Mechanical Transmissions, (MMT'00), Timişoara, pp: 39-44.

Antonescu, P., M. Oprean and F.I.T. Petrescu, 1985a. Contributions to the synthesis of oscillating cam mechanism and oscillating flat stick. Proceedings of the 4th International Symposium on Theory and Practice of Mechanisms, (TPM' 85), Bucharest.

Antonescu, P., M. Oprean and F.I.T. Petrescu, 1985b. At the projection of the oscillate cams, there are mechanisms and distribution variables. Proceedings of the 5th Conference of Engines, Automobiles, Tractors and Agricultural Machines, (AMA' 58), IMotors and Cars, Brasov.

Antonescu, P., M. Oprean and F.I.T. Petrescu, 1986. Projection of the profile of the rotating camshaft acting on the oscillating plate with disengagement. Proceedings of the 3rd National Computer-aided Design Symposium in the field of Mechanisms and Machine Parts, (MMP' 86), Brasov.

Antonescu, P., M. Oprean and F.I.T. Petrescu, 1987. Dynamic analysis of the cam distribution mechanisms. Proceedings of the 7th National Symposium on Industrial Robots and Space Mechanisms, (RSM' 87), Bucharest.

Antonescu, P., M. Oprean and FIT. Petrescu, 1988. Analytical synthesis of Kurz profile, rotating the flat cam. Machine, Build. Rev.

Ascione, F., N. Bianco, R.F. De Masi, F. De Rossi and C. De Stasio et al., 2016. Energy audit of health care facilities: Dynamic simulation of energy performances and energy-oriented refurbishment of system and equipment for microclimatic control. Am. J. Eng. Applied Sci., 9: 814-834. DOI: 10.3844 ajeassp.2016.814.834
Augustine, A., R.D. Prakash, R. Xavier and M.C. Parassery, 2016. Review of signal processing techniques for detection of power quality events. Am. J. Eng. Applied Sci., 9: 364-370. DOI: 10.3844/ajeassp.2016.364.370

Aversa, R., D. Parcesepe, R.V. Petrescu, G. Chen and F.I.T. Petrescu et al., 2016b. Glassy amorphous metal injection molded induced morphological defects. Am. J. Applied Sci., 13: 1476-1482.

DOI: 10.3844/ajassp.2016.1476.1482

Aversa, R., D. Parcesepe, R.V.V. Petrescu, F. Berto and G. Chen et al., 2017d. Process ability of bulk metallic glasses. Am. J. Applied Sci., 14: 294-301. DOI: 10.3844/ajassp.2017.294.301

Aversa, R., E.M. Buzea, R.V. Petrescu, A. Apicella and M. Neacsa et al., 2016e. Present a mechatronic system having able to determine the concentration of carotenoids. Am. J. Eng. Applied Sci., 9: 11061111. DOI: 10.3844/ajeassp.2016.1106.1111

Aversa, R., F. Tamburrino, R.V. Petrescu, F.I.T. Petrescu and M. Artur et al., 2016d. Biomechanically inspired shape memory effect machines driven by muscle like acting NiTi alloys. Am. J. Applied Sci., 13: 1264-1271.

DOI: 10.3844/ajassp.2016.1264.1271

Aversa, R., F.I.T. Petrescu, R.V. Petrescu and A. Apicella, 2016a. Biomimetic FEA bone modeling for customized hybrid biological prostheses development. Am. J. Applied Sci., 13: 1060-1067. DOI: 10.3844/ajassp.2016.1060.1067

Aversa, R., F.I.T. Petrescu, R.V. Petrescu and A. Apicella, 2016o. Flexible stem trabecular prostheses. Am. J. Eng. Applied Sci., 9: 1213-1221. DOI: 10.3844/ajeassp.2016.1213.122

Aversa, R., R.V. Petrescu, A. Apicella and F.I.T. Petrescu, 2016i. Mitochondria are naturally micro robots-a review. Am. J. Eng. Applied Sci., 9: 991-1002. DOI: 10.3844/ajeassp.2016.991.1002

Aversa, R., R.V. Petrescu, A. Apicella and F.I.T. Petrescu, 2016j. We are addicted to vitamins $\mathrm{C}$ and E-A review. Am. J. Eng. Applied Sci., 9: 10031018. DOI: 10.3844 /ajeassp.2016.1003.1018

Aversa, R., R.V. Petrescu, A. Apicella and F.I.T. Petrescu, 2016k. Physiologic human fluids and swelling behavior of hydrophilic biocompatible hybrid ceramo-polymeric materials. Am. J. Eng. Applied Sci., 9: 962-972. DOI: 10.3844/ajeassp.2016.962.972

Aversa, R., R.V. Petrescu, A. Apicella and F.I.T. Petrescu, 20161. One can slow down the aging through antioxidants. Am. J. Eng. Applied Sci., 9: 1112-1126. DOI: 10.3844/ajeassp.2016.1112.1126

Aversa, R., R.V. Petrescu, A. Apicella and F.I.T. Petrescu, 2016m. About homeopathy or «similia similibus curentur $\gg$. Am. J. Eng. Applied Sci., 9: 1164-1172. DOI: 10.3844/ajeassp.2016.1164.1172

Aversa, R., R.V. Petrescu, A. Apicella and F.I.T. Petrescu, 2016n. The basic elements of life's. Am. J. Eng. Applied Sci., 9: 1189-1197. DOI: 10.3844/ajeassp.2016.1189.1197 
Aversa, R., R.V. Petrescu, A. Apicella, F.I.T. Petrescu and J.K. Calautit et al., 2017c. Something about the V engines design. Am. J. Applied Sci., 14: 34-52. DOI: 10.3844/ajassp.2017.34.52

Aversa, R., R.V. Petrescu, B. Akash, R.B. Bucinell and J.M. Corchado et al., 2017b. Kinematics and forces to a new model forging manipulator. Am. J. Applied Sci., 14: 60-80. DOI: 10.3844/ajassp.2017.60.80

Aversa, R., R.V. Petrescu, F.I.T. Petrescu and A. Apicella, 2016c. Smart-factory: Optimization and process control of composite centrifuged pipes. Am. J. Applied Sci., 13: 1330-1341. DOI: 10.3844 /ajassp.2016.1330.1341

Aversa, R., R.V. Petrescu, F.I.T. Petrescu and A. Apicella, 2016h. Biomimetic and evolutionary design driven innovation in sustainable products development. Am. J. Eng. Applied Sci., 9: 1027-1036. DOI: 10.3844/ajeassp.2016.1027.1036

Aversa, R., R.V. Petrescu, R. Sorrentino, F.I.T. Petrescu and A. Apicella, 2016f. Hybrid ceramo-polymeric nanocomposite for biomimetic scaffolds design and preparation. Am. J. Eng. Applied Sci., 9: 1096-1105. DOI: 10.3844/ajeassp.2016.1096.1105

Aversa, R., R.V.V. Petrescu, A. Apicella and F.I.T. Petrescu, 2017a. Nano-diamond hybrid materials for structural biomedical application. Am. J. Biochem. Biotechnol., 13: 34-41. DOI: 10.3844/ajbbsp.2017.34.41

Aversa, R., R.V.V. Petrescu, B. Akash, R.B. Bucinell and J.M. Corchado et al., 2017e. Something about the balancing of thermal motors. Am. J. Eng. Applied Sci., 10: 200.217.

DOI: 10.3844/ajeassp.2017.200.217

Aversa, R., V. Perrotta, R.V. Petrescu, C. Misiano and F.I.T. Petrescu et al., 2016g. From structural colors to super-hydrophobicity and achromatic transparent protective coatings: Ion plating plasma assisted $\mathrm{TiO} 2$ and $\mathrm{SiO} 2$ nano-film deposition. Am. J. Eng. Applied Sci., 9: 1037-1045.

DOI: 10.3844/ajeassp.2016.1037.1045

Babayemi, A.K., 2016. Thermodynamics, non-linear isotherms, statistical modeling and optimization of phosphorus adsorption from wastewater. Am. J. Eng. Applied Sci., 9: 1019-1026.

DOI: 10.3844/ajeassp.2016.1019.1026

Bakar, R.A., M.K. Mohammed and M.M. Rahman, 2009. Numerical study on the performance characteristics of hydrogen fueled port injection internal combustion engine. Am. J. Eng. Applied Sci., 2: 407-415.

DOI: 10.3844/ajeassp.2009.407.415

Barone, G., A. Buonomano, C. Forzano and A. Palombo, 2016. WLHP systems in commercial buildings: A case study analysis based on a dynamic simulation approach. Am. J. Eng. Applied Sci., 9: 659-668. DOI: 10.3844/ajeassp.2016.659.668
Bedon, C. and C. Amadio, 2016. A unified approach for the shear buckling design of structural glass walls with non-ideal restraints. Am. J. Eng. Applied Sci., 9: 64-78. DOI: 10.3844/ajeassp.2016.64.78

Bedon, C. and C. Louter, 2016. Finite-element numerical simulation of the bending performance of posttensioned structural glass beams with adhesively bonded CFRP tendons. Am. J. Eng. Applied Sci., 9: 680-691. DOI: 10.3844/ajeassp.2016.680.691

Bedon, C., 2016. Review on the use of FRP composites for facades and building skins. Am. J. Eng. Applied Sci., 9: 713-723. DOI: 10.3844/ajeassp.2016.713.723

Bier, H. and S. Mostafavi, 2015. Structural optimization for materially informed design to robotic production processes. Am. J. Eng. Applied Sci., 8: 549-555. DOI: 10.3844/ajeassp.2015.549.555

Bolonkin, A., 2009a. Femtotechnology: Nuclear matter with fantastic properties. Am. J. Eng. Applied Sci., 2: 501-514. DOI: 10.3844/ajeassp.2009.501.514

Bolonkin, A., 2009b. Converting of matter to nuclear energy by ab-generator. Am. J. Eng. Applied Sci., 2: 683-693. DOI: 10.3844/ajeassp.2009.683.693

Boucetta, A., 2008. Vector control of a variable reluctance machine stator and rotor discs imbricates. Am. J. Eng. Applied Sci., 1: 260-265. DOI: 10.3844/ajeassp.2008.260.265

Bourahla, N. and A. Blakeborough, 2015. Similitude distortion compensation for a small scale model of a knee braced steel frame. Am. J. Eng. Applied Sci., 8: 481-488. DOI: 10.3844/ajeassp.2015.481.488

Bucinell, R.B., 2016. Stochastic model for variable amplitude fatigue induced delamination growth in graphite/epoxy laminates. Am. J. Eng. Applied Sci., 9: 635-646. DOI: 10.3844/ajeassp.2016.635.646

Budak, S., Z. Xiao, B. Johnson, J. Cole, M. Drabo and A. Tramble et al., 2016. Highly-efficient advanced thermoelectric devices from different multilayer thin films. Am. J. Eng. Applied Sci., 9: 356-363. DOI: 10.3844/ajeassp.2016.356.363

Buonomano, A., F. Calise and M. Vicidomini, 2016a. A novel prototype of a small-scale solar power plant: dynamic simulation and thermoeconomic analysis. Am. J. Eng. Applied Sci., 9: 770-788. DOI: 10.3844/ajeassp.2016.770.788

Buonomano, A., F. Calise, M.D. d'Accadia, R. Vanoli and M. Vicidomini, 2016b. Simulation and experimental analysis of a demonstrative solar heating and cooling plant installed in Naples (Italy). Am. J. Eng. Applied Sci., 9: 798-813. DOI: 10.3844/ajeassp.2016.798.813

Calise, F., M.D. Dâ' Accadia, L. Libertini, E. Quiriti and M. Vicidomini, 2016b. Dynamic simulation and optimum operation strategy of a trigeneration system serving a hospital. Am. J. Eng. Applied Sci., 9: 854-867. DOI: 10.3844/ajeassp.2016.854.867 
Campo, T., M. Cotto, F. Marquez, E. Elizalde and C. Morant, 2016. Graphene synthesis by plasmaenhanced CVD growth with ethanol. Am. J. Eng. Applied Sci., 9: 574-583.

DOI: 10.3844 ajeassp.2016.574.583

Cao, W., H. Ding, Z. Bin and C. Ziming, 2013. New structural representation and digital-analysis platform for symmetrical parallel mechanisms. Int. J. Adv. Robotic Syst.

Cardu, M., P. Oreste and T. Cicala, 2009. Analysis of the tunnel boring machine advancement on the bolognaflorence railway link. Am. J. Eng. Applied Sci., 2: 416-420. DOI: 10.3844/ajeassp.2009.416.420

Casadei, D., 2015. Bayesian statistical inference for number counting experiments. Am. J. Eng. Applied Sci., 8: 730-735. DOI: 10.3844/ajeassp.2015.730.735

Cataldo, R., 2006. Overview of planetary power system options for education. ITEA Human Exploration Project Authors, at Glenn Research Center, Brooke Park, OH.

Chang, S.P., M.C. Chen and J.D. Lin, 2015. Study of heat-treated steel and related applications. Am. J. Eng. Applied Sci., 8: 611-619.

DOI: 10.3844/ajeassp.2015.611.619

Chen, G. and L. Xu, 2016. A general strategy to enhance upconversion luminescence in rare-earth-iondoped oxide nanocrystals. Am. J. Eng. Applied Sci., 9: 79-83. DOI: 10.3844/ajeassp.2016.79.83

Chiozzi, A., G. Milani, N. Grillanda and A. Tralli, 2016. An adaptive procedure for the limit analysis of FRP reinforced masonry vaults and applications. Am. J. Eng. Applied Sci., 9: 735-745.

DOI: 10.3844 /ajeassp.2016.735.745

Chisari, C. and C. Bedon, 2016. Multi-objective optimization of FRP jackets for improving the seismic response of reinforced concrete frames. Am. J. Eng. Applied Sci., 9: 669-679. DOI: 10.3844/ajeassp.2016.669.679

Comanescu, A., 2010. Bazele Modelarii Mecanismelor. 1st Edn., E. Politeh, Press, Bucureşti, pp: 274.

Darabi, A., S.A. Soleamani and A. Hassannia, 2008. Fuzzy based digital automatic voltage regulator of a synchronous generator with unbalanced loads. Am. J. Eng. Applied Sci., 1: 280-286. DOI: 10.3844/ajeassp.2008.280.286

Daud, H., N. Yahya, A.A. Aziz and M.F. Jusoh, 2008. Development of wireless electric concept powering electrical appliances. Am. J. Eng. Applied Sci., 1: 12-15. DOI: 10.3844/ajeassp.2008.12.15

Demetriou, D., N. Nikitas and K.D. Tsavdaridis, 2015. Semi active tuned mass dampers of buildings: A simple control option. Am. J. Eng. Applied Sci., 8: 620-632. DOI: 10.3844/ajeassp.2015.620.632
Dixit, S. and S. Pal, 2015. Synthesis and characterization of ink (carbon)-perovskite/polyaniline ternary composite electrode for sodium chloride separation. Am. J. Eng. Applied Sci., 8: 527-537. DOI: 10.3844 /ajeassp.2015.527.537

Djalel, D., M. Mourad and H. Labar, 2013. New approach of electromagnetic fields of the lightning discharge. Am. J. Eng. Applied Sci., 6: 369-383. DOI: 10.3844/ajeassp.2013.369.383

Dong, H., N. Giakoumidis, N. Figueroa and N. Mavridis, 2013. Approaching behaviour monitor and vibration indication in developing a General Moving Object Alarm System (GMOAS). Int. J. Adv. Robotic Syst.

Santos, D.F.A. and C. Bedon, 2016. Preliminary experimental and finite-element numerical assessment of the structural performance of SMAreinforced GFRP systems. Am. J. Eng. Applied Sci., 9: 692-701. DOI: 10.3844/ajeassp.2016.692.701

Ebrahim, N.A., S. Ahmed, S.H.A. Rashid and Z. Taha, 2012. Technology use in the virtual $\mathrm{R}$ and D teams. Am. J. Eng. Applied Sci., 5: 9-14. DOI: 10.3844/ajeassp.2012.9.14

El-Labban, H.F., M. Abdelaziz and E.R.I. Mahmoud, 2013. Modification of carbon steel by laser surface melting: Part I: Effect of laser beam travelling speed on microstructural features and surface hardness. Am. J. Eng. Applied Sci., 6: 352-359. DOI: 10.3844/ajeassp.2013.352.359

Elliott, A., S. AlSalihi, A.L. Merriman and M.M. Basti, 2016. Infiltration of nanoparticles into porous binder jet printed parts. Am. J. Eng. Applied Sci., 9: 128133. DOI: 10.3844/ajeassp.2016.128.133

Elmeddahi, Y., H. Mahmoudi, A. Issaadi, M.F.A. Goosen and R. Ragab, 2016b. Evaluating the effects of climate change and variability on water resources: A case study of the Cheliff Basin in Algeria. Am. J. Eng. Applied Sci., 9: 835-845. DOI: 10.3844/ajeassp.2016.835.845

El-Tous, Y., 2008. Pitch angle control of variable speed wind turbine. Am. J. Eng. Applied Sci., 1: 118-120. DOI: 10.3844 /ajeassp.2008.118.120

Faizal, A., S. Mulyono, R. Yendra and A. Fudholi, 2016. Design Maximum Power Point Tracking (MPPT) on photovoltaic panels using fuzzy logic method. Am. J. Eng. Applied Sci., 9: 789-797. DOI: 10.3844/ajeassp.2016.789.797

Farahani, A.S., N.M. Adam and M.K.A. Ariffin, 2010. Simulation of airflow and aerodynamic forces acting on a rotating turbine ventilator. Am. J. Eng. Applied Sci., 3: 159-170. DOI: 10.3844/ajeassp.2010.159.170

Farokhi, E. and M. Gordini, 2015. Investigating the parameters influencing the behavior of knee braced steel structures. Am. J. Eng. Applied Sci., 8: 567-574. DOI: 10.3844/ajeassp.2015.567.574 
Fathallah, A.Z.M. and R.A. Bakar, 2009. Prediction studies for the performance of a single cylinder high speed spark ignition linier engine with spring mechanism as return cycle. Am. J. Eng. Applied Sci., 2: 713-720. DOI: 10.3844/ajeassp.2009.713.720

Fen, Y.W., W.M.M. Yunus, M.M. Moksin, Z.A. Talib and N.A. Yusof, 2011. Optical properties of crosslinked chitosan thin film with glutaraldehyde using surface plasmon resonance technique. Am. J. Eng. Applied Sci., 4: 61-65. DOI: 10.3844/ajeassp.2011.61.65

Feraga, C.E., A. Moussaoui, A. Bouldjedri and A. Yousfi, 2009. Robust position controller for a permanent magnet synchronous actuator. Am. J. Eng. Applied Sci., 2: 388-392. DOI: 10.3844/ajeassp.2009.388.392

Franklin, D.J., 1930. Ingenious Mechanisms for Designers and Inventors. 1st Edn., Industrial Press Publisher.

Fu, Y.F., J. Gong, H. Huang, Y.J. Liu, D. Zhu and P.F. Zhao, 2015. Parameters optimization of adaptive cashew shelling cutter based on BP neural network and genetic algorithm. Am. J. Eng. Applied Sci., 8: 648-658. DOI: 10.3844/ajeassp.2015.648.658

Ge, L. and X. Xu, 2015. A scheme design of cloud+end technology in demand side management. Am. J. Eng. Applied Sci., 8: 736-747. DOI: 10.3844/ajeassp.2015.736.747

Gruener, J.E., 2006. Lunar exploration (Presentation to ITEA Human Exploration Project Authors, at Johnson Space Center). Houston, TX.

Gupta, P., A. Gupta and A. Asati, 2015. Ultra low power MUX based compressors for wallace and dadda multipliers in sub-threshold regime. Am. J. Eng. Applied Sci., 8: 702-716. DOI: 10.3844 ajeassp.2015.702.716

Gusti, A.P. and Semin, 2016. The effect of vessel speed on fuel consumption and exhaust gas emissions. Am. J. Eng. Applied Sci., 9: 1046-1053. DOI: 10.3844/ajeassp.2016.1046.1053

Hasan, S. and M.H. El-Naas, 2016. Optimization of a combined approach for the treatment of carbide slurry and capture of CO2. Am. J. Eng. Applied Sci., 9: 449457. DOI: 10.3844/ajeassp.2016.449.457

Hassan, M., H. Mahjoub and M. Obed, 2012. Voice-based control of a DC servo motor. Am. J. Eng. Applied Sci., 5: 89-92. DOI: 10.3844/ajeassp.2012.89.92

He, B., Z. Wang, Q. Li, H. Xie and R. Shen, 2013. An analytic method for the kinematics and dynamics of a multiple-backbone continuum robot. IJARS.

Helmy, A.K. and G.S. El-Taweel, 2010. Neural network change detection model for satellite images using textural and spectral characteristics. Am. J. Eng. Applied Sci., 3: 604-610. DOI: 10.3844 ajeassp.2010.604.610

Hirun, W., 2016. Evaluation of interregional freight generation modelling methods by using nationwide commodity flow survey data. Am. Eng. Applied Sci., 9: 625-634. DOI: 10.3844/ajeassp.2016.625.634
Ho, C.Y.F., B.W.K. Ling, S.G. Blasi, Z.W. Chi and W.C. Siu, 2011. Single step optimal block matched motion estimation with motion vectors having arbitrary pixel precisions. Am. J. Eng. Applied Sci., 4: 448-460. DOI: 10.3844/ajeassp.2011.448.460

Huang, B., S.H. Masood, M. Nikzad, P.R. Venugopal and A. Arivazhagan, 2016. Dynamic mechanical properties of fused deposition modelling processed polyphenylsulfone material. Am. J. Eng. Applied Sci., 9: 1-11. DOI: 10.3844/ajeassp.2016.1.11

Idarwazeh, S., 2011. Inverse discrete fourier transformdiscrete fourier transform techniques for generating and receiving spectrally efficient frequency division multiplexing signals. Am. J. Eng. Applied Sci., 4: 598-606. DOI: 10.3844/ajeassp.2011.598.606

Iqbal, M., 2016. An overview of Energy Loss Reduction (ELR) software used in pakistan by WAPDA for calculating transformer overloading, line losses and energy losses. Am. J. Eng. Applied Sci., 9: 442-448. DOI: 10.3844/ajeassp.2016.442.448

Ismail, M.I.S., Y. Okamoto, A. Okada and Y. Uno, 2011. Experimental investigation on micro-welding of thin stainless steel sheet by fiber laser. Am. J. Eng. Applied Sci., 4: 314-320. DOI: 10.3844/ajeassp.2011.314.320

Jaber, A.A. and R. Bicker, 2016. Industrial robot fault detection based on statistical control chart. Am. J. Eng. Applied Sci., 9: 251-263.

DOI: 10.3844/ajeassp.2016.251.263

Jafari, N., A. Alsadoon, C.P. Withana, A. Beg and A. Elchouemi, 2016. Designing a comprehensive security framework for smartphones and mobile devices. Am. J. Eng. Applied Sci., 9: 724-734. DOI: 10.3844/ajeassp.2016.724.734

Jalil, M.I.A. and J. Sampe, 2013. Experimental investigation of thermoelectric generator modules with different technique of cooling system. Am. J. Eng. Applied Sci., 6: 1-7. DOI: 10.3844/ajeassp.2013.1.7

Jaoude, A.A. and K. El-Tawil, 2013. Analytic and nonlinear prognostic for vehicle suspension systems. Am. J. Eng. Applied Sci., 6: 42-56. DOI: 10.3844 /ajeassp.2013.42.56

Jarahi, H. and S. Seifilaleh, 2016. Rock fall hazard zonation in haraz highway. Am. J. Eng. Applied Sci., 9: 371-379. DOI: 10.3844/ajeassp.2016.371.379

Jarahi, H., 2016. Probabilistic seismic hazard deaggregation for Karaj City (Iran). Am. J. Eng. Applied Sci., 9: 520-529.

DOI: $10.3844 /$ ajeassp.2016.520.529

Jauhari, K., A. Widodo and I. Haryanto, 2016. Identification of a machine tool spindle critical frequency through modal and imbalance response analysis. Am. J. Eng. Applied Sci., 9: 213-221. DOI: 10.3844/ajeassp.2016.213.221

Jiang, J., Q. Chen and S. Nimbalkar, 2016. Field data based method for predicting long-term settlements. Am. J. Eng. Applied Sci., 9: 466-476. DOI: 10.3844/ajeassp.2016.466.476 
Jones, J.R. and J.E. Reeve, 1974. Dynamic Response of Cam Curves Based on Sinusoidal Segments. In: Cams and Cam Mechanisms, Jones, J.R. (Ed.), MEP, London and Birmingham, Alabama.

Kaewnai, S. and S. Wongwises, 2011. Improvement of the runner design of francis turbine using computational fluid dynamics. Am. J. Eng. Applied Sci., 4: 540-547. DOI: 10.3844/ajeassp.2011.540.547

Kamble, V.G. and N.L. Kumar, 2016. Fabrication and tensile property analysis of polymer matrix composites of graphite and silicon carbide as fillers. Am. J. Eng. Applied Sci., 9: 17-30. DOI: 10.3844/ajeassp.2016.17.30

Kazakov, V.V., V.I. Yusupov, V.N. Bagratashvili, A.I. Pavlikov and V.A. Kamensky, 2016. Control of bubble formation at the optical fiber tip by analyzing ultrasound acoustic waves. Am. J. Eng. Applied Sci., 9: 921-927. DOI: 10.3844/ajeassp.2016.921.927

Kechiche, O.B.H.B., H.B.A. Sethom, H. Sammoud and I.S. Belkhodja, 2011. Optimized high-frequency signal injection based permanent magnet synchronous motor rotor position estimation applied to washing machines. Am. J. Eng. Applied Sci., 4: 390-399. DOI: 10.3844/ajeassp.2011.390.399

Khalifa, A.H.N., A.H. Jabbar and J.A. Muhsin, 2015. Effect of exhaust gas temperature on the performance of automobile adsorption airconditioner. Am. J. Eng. Applied Sci., 8: 575-581. DOI: 10.3844/ajeassp.2015.575.581

Khalil, R., 2015. Credibility of 3D volume computation using GIS for pit excavation and roadway constructions. Am. J. Eng. Applied Sci., 8: 434-442. DOI: 10.3844/ajeassp.2015.434.442

Kuli, I., T.M. Abu-Lebdeh, E.H. Fini and S.A. Hamoush, 2016. The use of nano-silica for improving mechanical properties of hardened cement paste. Am. J. Eng. Applied Sci., 9: 146-154. DOI: 10.3844/ajeassp.2016.146.154

Kumar, N.D., R.D. Ravali and P.R. Srirekha, 2015. Design and realization of pre-amplifier and filters for on-board radar system. Am. J. Eng. Applied Sci., 8: 689-701. DOI: 10.3844/ajeassp.2015.689.701

Kunanoppadon, J., 2010. Thermal efficiency of a combined turbocharger set with gasoline engine. Am. J. Eng. Applied Sci., 3: 342-349. DOI: 10.3844/ajeassp.2010.342.349

Kwon, S., Y. Tani, H. Okubo and T. Shimomura, 2010. Fixed-star tracking attitude control of spacecraft using single-gimbal control moment gyros. Am. J. Eng. Applied Sci., 3: 49-55. DOI: 10.3844 /ajeassp.2010.49.55

Lamarre, A., E.H. Fini and T.M. Abu-Lebdeh, 2016. Investigating effects of water conditioning on the adhesion properties of crack sealant. Am. J. Eng. Applied Sci., 9: 178-186.

DOI: $10.3844 /$ ajeassp.2016.178.186
Lee, B.J., 2013. Geometrical derivation of differential kinematics to calibrate model parameters of flexible manipulator. Int. J. Adv. Robotic Syst.

Li, R., B. Zhang, S. Xiu, H. Wang, L. Wang and A. Shahbazi, 2015. Characterization of solid residues obtained from supercritical ethanol liquefaction of swine manure. Am. J. Eng. Applied Sci., 8: 465-470. DOI: 10.3844/ajeassp.2015.465.470

Lin, W., B. Li, X. Yang and D. Zhang, 2013. Modelling and control of inverse dynamics for a 5-DOF parallel kinematic polishing machine. Int. J. Adv. Robotic Syst.

Liu, H., W. Zhou, X. Lai and S. Zhu, 2013. An efficient inverse kinematic algorithm for a PUMA560structured robot manipulator. IJARS.

Lubis, Z. .A.N. Abdalla, Mortaza and R. Ghon, 2009b. Mathematical modeling of the three phase induction motor couple to DC motor in hybrid electric vehicle. Am. J. Eng. Applied Sci., 2: 708-712. DOI: 10.3844 /ajeassp.2009.708.712

Madani, D.A. and A. Dababneh, 2016. Rapid entire body assessment: A literature review. Am. J. Eng. Applied Sci., 9: 107-118. DOI: 10.3844/ajeassp.2016.107.118

Malomar, G.E.B., A. Gueye, C. Mbow, V.B. Traore and A.C. Beye, 2016. Numerical study of natural convection in a square porous cavity thermally modulated on both side walls. Am. J. Eng. Applied Sci., 9: 591-598. DOI: 10.3844/ajeassp.2016.591.598

Mansour, M.A.A., 2016. Developing an anthropometric database for saudi students and comparing saudi dimensions relative to Turkish and Iranian peoples. Am. J. Eng. Applied Sci., 9: 547-557. DOI: 10.3844/ajeassp.2016.547.557

Maraveas, C., Z.C. Fasoulakis and K.D. Tsavdaridis, 2015. A review of human induced vibrations on footbridges. Am. J. Eng. Applied Sci., 8: 422-433. DOI: 10.3844 /ajeassp.2015.422.433

Marghany, M. and M. Hashim, 2009. Robust of doppler centroid for mapping sea surface current by using radar satellite data. Am. J. Eng. Applied Sci., 2: 781-788. DOI: 10.3844/ajeassp.2009.781.788

Martins, F.R., A.R. Gonçalves and E.B. Pereira, 2016. Observational study of wind shear in northeastern Brazil. Am. J. Eng. Applied Sci., 9: 484-504. DOI: 10.3844/ajeassp.2016.484.504

Marzuki, M.A.1.B., M.H. Abd Halim and A.R.N. Mohamed, 2015. Determination of natural frequencies through modal and harmonic analysis of space frame race car chassis based on ANSYS. Am. J. Eng. Applied Sci., 8: 538-548. DOI: 10.3844/ajeassp.2015.538.548

Mavukkandy, M.O., S. Chakraborty, T. Abbasi and S.A. Abbasi, 2016. A clean-green synthesis of platinum nanoparticles utilizing a pernicious Weed Lantana (Lantana Camara). Am. J. Eng. Applied Sci., 9: 84-90. DOI: 10.3844/ajeassp.2016.84.90 
Minghini, F., N. Tullini and F. Ascione, 2016. Updating italian design guide CNR DT-205/2007 in view of recent research findings: Requirements for pultruded FRP profiles. Am. J. Eng. Applied Sci., 9: 702-712. DOI: 10.3844/ajeassp.2016.702.712

Moezi, N., D. Dideban and A. Ketabi, 2008. A novel integrated SET based inverter for nano power electronic applications. Am. J. Eng. Applied Sci., 1: 219-222. DOI: 10.3844/ajeassp.2008.219.222

Mohamed, M.A., A.Y. Tuama, M. Makhtar, M.K. Awang and M. Mamat, 2016. The effect of RSA exponential key growth on the multi-core computational resource. Am. J. Eng. Applied Sci., 9: 1054-1061. DOI: 10.3844/ajeassp.2016.1054.1061

Mohan, K.SR., P. Jayabalan and A. Rajaraman, 2012. Properties of fly ash based coconut fiber composite. Am. J. Eng. Applied Sci., 5: 29-34. DOI: 10.3844/ajeassp.2012.29.34

Mohseni, E. and K.D. Tsavdaridis, 2016. Effect of nanoalumina on pore structure and durability of class f fly ash self-compacting mortar. Am. J. Eng. Applied Sci., 9: 323-333. DOI: 10.3844/ajeassp.2016.323.333

Momani, M.A., T.A. Al Smadi, F.M. Al Taweel and K.A. Ghaidan, 2011. GPS ionospheric total electron content and scintillation measurements during the October 2003 magnetic storm. Am. J. Eng. Applied Sci., 4: 301-306. DOI: 10.3844/ajeassp.2011.301.306

Momta, P.S., J.O. Omoboh and M.I. Odigi, 2015. Sedimentology and depositional environment of D2 sand in part of greater ughelli depobelt, onshore Niger Delta, Nigeria. Am. J. Eng. Applied Sci., 8: 556-566. DOI: 10.3844/ajeassp.2015.556.566

Mondal, R., S. Sahoo and C.S. Rout, 2016. Mixed nickel cobalt manganese oxide nanorods for supercapacitor application. Am. J. Eng. Applied Sci., 9: 540-546. DOI: 10.3844/ajeassp.2016.540.546

Montgomery, J., T.M. Abu-Lebdeh, S.A. Hamoush and M. Picornell, 2016. Effect of nano-silica on the compressive strength of harden cement paste at different stages of hydration. Am. J. Eng. Applied Sci., 9: 166-177. DOI: 10.3844/ajeassp.2016.166.177

Moretti, M.L., 2015. Seismic design of masonry and reinforced concrete infilled frames: A comprehensive overview. Am. J. Eng. Applied Sci., 8: 748-766. DOI: 10.3844/ajeassp.2015.748.766

Morse, A., M.M. Mansfield, R.M. Alley, H.A. Kerr and R.B. Bucinell, 2016b. Traction enhancing products affect maximum torque at the shoe-floor interface: A potential increased risk of ACL injury. Am. J. Eng. Applied Sci., 9: 889-893.

DOI: $10.3844 /$ ajeassp.2016.889.893

Moubarek, T. and A. Gharsallah, 2016. A six-port reflectometer calibration using wilkinson power divider. Am. J. Eng. Applied Sci., 9: 274-280. DOI: 10.3844/ajeassp.2016.274.280
Nabilou, A., 2016a. Effect of parameters of selection and replacement drilling bits based on geomechanical factors: (Case study: Gas and oil reservoir in the southwest of Iran). Am. J. Eng. Applied Sci., 9: 380-395.

DOI: 10.3844 /ajeassp.2016.380.395

Nabilou, A., 2016b. Study of the parameters of Steam Assisted Gravity Drainage (SAGD) method for enhanced oil recovery in a heavy oil fractured carbonate reservoir. Am. J. Eng. Applied Sci., 9: 647-658. DOI: 10.3844/ajeassp.2016.647.658

Nachiengtai, T., W. Chim-Oye, S. Teachavorasinskun and W. Sa-Ngiamvibool, 2008. Identification of shear band using elastic shear wave propagation. Am. J. Eng. Applied Sci., 1: 188-191. DOI: 10.3844/ajeassp.2008.188.191

Nahas, R. and S.P. Kozaitis, 2014. Metric for the fusion of synthetic and real imagery from multimodal sensors. Am. J. Eng. Applied Sci., 7: 355-362. DOI: 10.3844/ajeassp.2014.355.362

Nandhakumar, S., V. Selladurai and S. Sekar, 2009. Numerical investigation of an industrial robot arm control problem using haar wavelet series. Am. J. Eng. Applied Sci., 2: 584-589.

DOI: 10.3844/ajeassp.2009.584.589

Ng, K.C., M.Z. Yusoff, K. Munisamy, H. Hasini and N.H. Shuaib, 2008. Time-marching method for computations of high-speed compressible flow on structured and unstructured grid. Am. J. Eng. Applied Sci., 1: 89-94. DOI: 10.3844/ajeassp.2008.89.94

Obaiys, S.J., Z. Abbas, N.M.A. Nik Long, A. F. Ahmad and A. Ahmedov et al., 2016. On the general solution of first-kind hypersingular integral equations. Am. J. Eng. Applied Sci., 9: 195-201. DOI: 10.3844/ajeassp.2016.195.201

Odeh, S., R. Faqeh, L. Abu Eid and N. Shamasneh, 2009. Vision-based obstacle avoidance of mobile robot using quantized spatial model. Am. J. Eng. Applied Sci., 2: 611-619. DOI: 10.3844 /ajeassp.2009.611.619

Ong, A.T., A. Mustapha, Z.B. Ibrahim, S. Ramli and B.C. Eong, 2015. Real-time automatic inspection system for the classification of PCB flux defects. Am. J. Eng. Applied Sci., 8: 504-518. DOI: 10.3844/ajeassp.2015.504.518

Opafunso, Z.O., I.I. Ozigis and I.A. Adetunde, 2009. Pneumatic and hydraulic systems in coal fluidized bed combustor. Am. J. Eng. Applied Sci., 2: 88-95. DOI: 10.3844/ajeassp.2009.88.95

Orlando, N. and E. Benvenuti, 2016. Advanced XFEM simulation of pull-out and debonding of steel bars and FRP-reinforcements in concrete beams. Am. J. Eng. Applied Sci., 9: 746-754. DOI: 10.3844/ajeassp.2016.746.754 
Padula, F. and V. Perdereau, 2013. An on-line path planner for industrial manipulators. Int. J. Adv. Robotic Syst.

Perumaal, S. and N. Jawahar, 2013. Automated trajectory planner of industrial robot for pick-andplace task. IJARS.

Pannirselvam, N., P.N. Raghunath and K. Suguna, 2008. Neural network for performance of glass fibre reinforced polymer plated RC beams. Am. J. Eng. Applied Sci., 1: 82-88.

DOI: 10.3844 /ajeassp.2008.82.88

Pattanasethanon, S., 2010. The solar tracking system by using digital solar position sensor. Am. J. Eng. Applied Sci., 3: 678-682. DOI: 10.3844 /ajeassp.2010.678.682

Pérez-de León, G., V.E. Lamberti, R.D. Seals, T.M. Abu-Lebdeh and S.A. Hamoush, 2016. Gas atomization of molten metal: Part I. numerical modeling conception. Am. J. Eng. Applied Sci., 9: 303-322. DOI: 10.3844/ajeassp.2016.303.322

Petrescu, F. and R. Petrescu, 1995a. Contributions to optimization of the polynomial motion laws of the stick from the internal combustion engine distribution mechanism. Bucharest, 1: 249-256.

Petrescu, F. and R. Petrescu, 1995b. Contributions to the synthesis of internal combustion engine distribution mechanisms. Bucharest, 1: 257-264.

Petrescu F.I.T. and R.V. Petrescu, 2015d. Presenting a rail bound forging manipulator. Applied Mecha. Materials, 762: 219-224.

Petrescu, F. and R. Petrescu, 1997a. Dynamics of cam mechanisms (exemplified on the classic distribution mechanism). Bucharest, 3: 353-358.

Petrescu, F. and R. Petrescu, 1997b. Contributions to the synthesis of the distribution mechanisms of internal combustion engines with a Cartesian coordinate method. Bucharest, 3: 359-364.

Petrescu, F. and R. Petrescu, 1997c. Contributions to maximizing polynomial laws for the active stroke of the distribution mechanism from internal combustion engines. Bucharest, 3: 365-370.

Petrescu, F. and R. Petrescu, 2000a. Synthesis of distribution mechanisms by the rectangular (Cartesian) coordinate method. Proceedings of the 8th National Conference on International Participation, (CIP' 00), Craiova, Romania, pp: 297-302.

Petrescu, F. and R. Petrescu, 2000b. The design (synthesis) of cams using the polar coordinate method (triangle method). Proceedings of the 8th National Conference on International Participation, (CIP' 00), Craiova, Romania, pp: 291-296.

Petrescu, F. and R. Petrescu, 2002a. Motion laws for cams. Proceedings of the International Computer Assisted Design, National Symposium with Participation, (SNP' 02), Braşov, pp: 321-326.

Petrescu, F. and R. Petrescu, 2002b. Camshaft dynamics elements. Proceedings of the International Computer Assisted Design, National Participation Symposium, (SNP' 02), Braşov, pp: 327-332.
Petrescu, F. and R. Petrescu, 2003. Some elements regarding the improvement of the engine design. Proceedings of the National Symposium, Descriptive Geometry, Technical Graphics and Design, (GTD' 03), Braşov, pp: 353-358.

Petrescu, F. and R. Petrescu, 2005a. The cam design for a better efficiency. Proceedings of the International Conference on Engineering Graphics and Design, (EGD' 05), Bucharest, pp: 245-248.

Petrescu, F. and R. Petrescu, 2005b. Contributions at the dynamics of cams. Proceedings of the 9th IFToMM International Symposium on Theory of Machines and Mechanisms, (TMM' 05), Bucharest, Romania, pp: 123-128.

Petrescu, F. and R. Petrescu, 2005c. Determining the dynamic efficiency of cams. Proceedings of the 9th IFToMM International Symposium on Theory of Machines and Mechanisms, (TMM' 05), Bucharest, Romania, pp: 129-134.

Petrescu, F. and R. Petrescu, 2005d. An original internal combustion engine. Proceedings of the 9th IFToMM International Symposium on Theory of Machines and Mechanisms, (TMM' 05), Bucharest, Romania, pp: 135-140.

Petrescu, F. and R. Petrescu, 2005e. Determining the mechanical efficiency of Otto engine's mechanism. Proceedings of the 9th IFToMM International Symposium on Theory of Machines and Mechanisms, (TMM 05), Bucharest, Romania, pp: 141-146.

Petrescu, F.I. and R.V. Petrescu, 2011a. Mechanical Systems, Serial and Parallel (Romanian). 1st Edn., LULU Publisher, London, UK, pp: 124.

Petrescu, F.I. and R.V. Petrescu, 2012a. Kinematics of the planar quadrilateral mechanism. ENGEVISTA, 14: 345-348.

Petrescu, F.I. and R.V. Petrescu, 2012b. MecatronicaSisteme Seriale si Paralele. 1st Edn., Create Space Publisher, USA, pp: 128.

Petrescu, F.I. and R.V. Petrescu, 2013a. Cinematics of the 3R dyad. ENGEVISTA, 15: 118-124.

Petrescu, F.I. and R.V. Petrescu, 2016a. Parallel moving mechanical systems kinematics. ENGEVISTA, 18: 455-491.

Petrescu, F.I. and R.V. Petrescu, 2016b. Direct and inverse kinematics to the anthropomorphic robots. ENGEVISTA, 18: 109-124.

Petrescu, F.I. and R.V. Petrescu, 2016c. Dynamic cinematic to a structure 2R. Revista Geintec-Gestao Inovacao E Tecnol., 6: 3143-3154.

Petrescu, F.I., B. Grecu, A. Comanescu and R.V. Petrescu, 2009. Some mechanical design elements. Proceeding of the International Conference on Computational Mechanics and Virtual Engineering, (MVE' 09), Braşov, pp: 520-525. 
Petrescu, F.I.T. A. Apicella, A. Raffaella, R.V. Petrescu and J.K. Calautit et al., 2016. Something about the mechanical moment of inertia. Am. J. Applied Sci., 13: 1085-1090. DOI: 10.3844/ajassp.2016.1085.1090

Petrescu, F.I.T. and R.V. Petrescu, 2013b. Forces and efficiency of cams. Int. Rev. Mechanic. Eng. J., 7: 507-511.

Petrescu, F.I.T. and R.V. Petrescu, 2013c. Cams with high efficiency. Int. Rev. Mechanic. Eng. J., 7: 599-606.

Petrescu, F.I.T. and R.V. Petrescu, 2013d. An algorithm for setting the dynamic parameters of the classic distribution mechanism. Int. Rev. Model. Simulat. J., 6: 1637-1641.

Petrescu, F.I.T. and R.V. Petrescu, 2013e. Dynamic synthesis of the rotary cam and translated tappet with roll, Int. Rev. Model. Simulat. J., 6: 600-607.

Petrescu, F.I.T. and R.V. Petrescu, 2014a. Parallel moving mechanical systems. Indepe. J. Manag. Product., 5: 564-580.

Petrescu, F.I.T. and R.V. Petrescu, 2014b. Cam gears dynamics in the classic distribution, Indepe. J. Manag. Product., 5: 166-185

Petrescu, F.I.T. and R.V. Petrescu, 2014c. Highefficiency gears synthesis by avoid the interferences. Indepe. J. Manag. Product., 5: 275-298.

Petrescu, F.I.T. and R.V. Petrescu, 2014d. Gear design. J. ENGEVISTA, 16: 313-328.

Petrescu, F.I.T. and R.V. Petrescu, 2014e. Kinetostatic of the $3 \mathrm{R}$ dyad (or $2 \mathrm{R}$ module). J. ENGEVISTA, 16: 314-321.

Petrescu, F.I.T. and R.V. Petrescu, 2014f. Balancing otto engines. Int. Rev. Mechanic. Eng. J., 8: 473-480.

Petrescu, F.I.T. and R.V. Petrescu, 2014g. Machine equations to the classical distribution. Int. Rev. Mechanic. Eng. J., 8: 309-316.

Petrescu, F.I.T. and R.V. Petrescu, 2014h. Forces of internal combustion heat engines. Int. Rev. Model. Simulat. J., 7: 206-212.

Petrescu, F.I.T. and R.V. Petrescu, 2014i. Determination of the yield of internal combustion thermal engines. Int. Rev. Mechanic. Eng. J., 8: 62-67.

Petrescu, F.I.T. and R.V. Petrescu, 2015a. Forces at the main mechanism of a rail bound forging manipulator. Indepe. J. Manag. Product., 6: 904-921.

Petrescu, F.I.T. and R.V. Petrescu, 2015b. Kinematics at the main mechanism of a rail bound forging manipulator. Indepe. J. Manag. Product., 6: 711-729.

Petrescu, F.I.T. and R.V. Petrescu, 2015c. Machine motion equations. Indepe. J. Manag. Product., 6: 773-802.

Petrescu, F.I.T. and R.V. Petrescu, 2015e. About the anthropomorphic robots. J. ENGEVISTA, 17: 1-15.

Petrescu, F.I.T., 2008. Ph.D. Thesis, Theoretical and Applied Contributions About the Dynamic of Planar Mechanisms with Superior Linkages. Bucharest Polytechnic University.
Petrescu, F.I.T., 2011. Teoria Mecanismelor si a Masinilor: Curs Si Aplicatii. 1st Edn., CreateSpace Independent Publishing Platform, ISBN-10: 1468015826. pp: 432.

Petrescu, F.I.T., 2015a. Geometrical synthesis of the distribution mechanisms. Am. J. Eng. Applied Sci., 8: 63-81. DOI: 10.3844/ajeassp.2015.63.81

Petrescu, F.I.T., 2015b. Machine motion equations at the internal combustion heat engines. Am. J. Eng. Applied Sci., 8: 127-137. DOI: 10.3844/ajeassp.2015.127.137

Petrescu, F.I.T. and R.V. Petrescu, 2011b. Trenuri Planetare. 1st Edn., Createspace Independent Pub., ISBN-13: 978-1468030419. pp: 104.

Petrescu, F.I.T. and RV. Petrescu, 2016d. An Otto Engine Dynamic Model. Indepe. J. Manag. Product., 7: 038-048.

Petrescu, R.V., R. Aversa, A. Apicella and F.I. Petrescu, 2016. Future medicine services robotics. Am. J. Eng. Applied Sci., 9: 1062-1087. DOI: 10.3844 /ajeassp.2016.1062.1087

Petrescu, R.V., R. Aversa, A. Apicella and F.I.T. Petrescu, 2017k. Transportation engineering. Am. J. Eng. Applied Sci., 10: 685-702.

DOI: 10.3844 /ajeassp.2017.685.702

Petrescu, R.V., R. Aversa, A. Apicella and F.I.T. Petrescu, 2018c. Friendly environmental transport. Am. J. Eng. Applied Sci., 11: 154-165. DOI: 10.3844 /ajeassp.2018.154.165

Petrescu, R.V., R. Aversa, A. Apicella and F.I.T. Petrescu, 2018j. Romanian engineering "on the wings of the wind". J. Aircraft Spacecraft Technol., 2: 1-18. DOI: $10.3844 /$ jastsp.2018.1.18

Petrescu, R.V., R. Aversa, A. Apicella and F.I.T. Petrescu, 2018k. NASA data used to discover eighth planet circling distant star. J. Aircraft Spacecraft Technol., 2: 19-30. DOI: 10.3844/jastsp.2018.19.30

Petrescu, R.V., R. Aversa, A. Apicella and F.I.T. Petrescu, 20181. NASA has found the most distant black hole. J. Aircraft Spacecraft Technol., 2: 31-39. DOI: 10.3844 jastsp.2018.31.39

Petrescu, R.V., R. Aversa, A. Apicella and F.I.T. Petrescu, $2018 \mathrm{~m}$. Nasa selects concepts for a new mission to titan, the moon of saturn. J. Aircraft Spacecraft Technol., 2: 40-52. DOI: 10.3844/jastsp.2018.40.52

Petrescu, R.V., R. Aversa, A. Apicella and F.I.T. Petrescu, 2018n. NASA sees first in 2018 the direct proof of ozone hole recovery. J. Aircraft Spacecraft Technol., 2: 53-64. DOI: 10.3844/jastsp.2018.53.64

Petrescu, R.V., R. Aversa, A. Apicella, M.M. Mirsayar and S. Kozaitis et al., 2018a. NASA started a propeller set on board voyager 1 after 37 years of break. Am. J. Eng. Applied Sci., 11: 66-77. DOI: 10.3844/ajeassp.2018.66.77 
Petrescu, R.V., R. Aversa, A. Apicella, M.M. Mirsayar and S. Kozaitis et al., 2018b. There is life on mars? Am. J. Eng. Applied Sci., 11: 78-91. DOI: 10.3844/ajeassp.2018.78.91

Petrescu, R.V., R. Aversa, B. Akash, B. Ronald and J. Corchado et al., 2017b. Velocities and accelerations at the 3R mechatronic systems. Am. J. Eng. Applied Sci., 10: 252-263. DOI: 10.3844/ajeassp.2017.252.263

Petrescu, R.V., R. Aversa, B. Akash, F. Berto and A. Apicella et al., 2017z. The modern flight. J. Aircraft Spacecraft Technol., 1: 224-233. DOI: $10.3844 /$ jastsp.2017.224.233

Petrescu, R.V., R. Aversa, B. Akash, F. Berto and A. Apicella et al., 2017aa. Sustainable energy for aerospace vessels. J. Aircraft Spacecraft Technol., 1: 234-240. DOI: 10.3844/jastsp.2017.234.240

Petrescu, R.V., R. Aversa, B. Akash, F. Berto and A. Apicella et al., 2017ab. Unmanned helicopters. J. Aircraft Spacecraft Technol., 1: 241-248. DOI: $10.3844 /$ jastsp.2017.241.248

Petrescu, R.V., R. Aversa, B. Akash, F. Berto and A. Apicella et al., 2017ac. Project HARP. J. Aircraft Spacecraft Technol., 1: 249-257. DOI: $10.3844 /$ jastsp.2017.249.257

Petrescu, R.V., R. Aversa, B. Akash, F. Berto and A. Apicella et al., 2017ad. Presentation of Romanian engineers who contributed to the development of global aeronautics-part I. J. Aircraft Spacecraft Technol., 1: 258-271.

DOI: $10.3844 /$ jastsp.2017.258.271

Petrescu, R.V., R. Aversa, B. Akash, F. Berto and A. Apicella et al., 2017ae. A first-class ticket to the planet mars, please. J. Aircraft Spacecraft Technol., 1: 272-281. DOI: 10.3844/jastsp.2017.272.281

Petrescu, R.V., R. Aversa, B. Akash, J. Corchado and F. Berto et al., 2017q. Our universe. J. Aircraft Spacecraft Technol., 1: 69-79. DOI: 10.3844/jastsp.2017.69.79

Petrescu, R.V., R. Aversa, B. Akash, J. Corchado and F. Berto et al., 2017r. What is a UFO? J. Aircraft Spacecraft Technol., 1: 80-90. DOI: 10.3844 /jastsp.2017.80.90

Petrescu, R.V., R. Aversa, B. Akash, J. Corchado and F. Berto et al., 2017s. About bell helicopter FCX-001 concept aircraft-a short review. J. Aircraft Spacecraft Technol., 1: 91-96. DOI: 10.3844/jastsp.2017.91.96

Petrescu, R.V., R. Aversa, B. Akash, J. Corchado and F. Berto et al., 2017t. Home at airbus. J. Aircraft Spacecraft Technol., 1: 97-118. DOI: $10.3844 /$ jastsp.2017.97.118

Petrescu, R.V., R. Aversa, B. Akash, J. Corchado and F. Berto et al., 2017u. Airlander. J. Aircraft Spacecraft Technol., 1: 119-148. DOI: $10.3844 /$ jastsp.2017.119.148

Petrescu, R.V., R. Aversa, B. Akash, J. Corchado and F. Berto et al., 2017v. When boeing is dreaming-a review. J. Aircraft Spacecraft Technol., 1: 149-161. DOI: $10.3844 /$ jastsp.2017.149.161
Petrescu, R.V., R. Aversa, B. Akash, J. Corchado and F. Berto et al., 2017w. About Northrop Grumman. J. Aircraft Spacecraft Technol., 1: 162-185. DOI: 10.3844/jastsp.2017.162.185

Petrescu, R.V., R. Aversa, B. Akash, J. Corchado and F. Berto et al., 2017x. Some special aircraft. J. Aircraft Spacecraft Technol., 1: 186-203. DOI: 10.3844/jastsp.2017.186.203

Petrescu, R.V., R. Aversa, B. Akash, J. Corchado and F. Berto et al., 2017y. About helicopters. J. Aircraft Spacecraft Technol., 1: 204-223. DOI: 10.3844/jastsp.2017.204.223

Petrescu, R.V., R. Aversa, B. Akash, R. Bucinell and J. Corchado et al., 2017a. Yield at thermal engines internal combustion. Am. J. Eng. Applied Sci., 10: 243-251. DOI: 10.3844/ajeassp.2017.243.251

Petrescu, R.V., R. Aversa, B. Akash, R. Bucinell and J. Corchado et al., 2017c. Anthropomorphic solid structures n-r kinematics. Am. J. Eng. Applied Sci., 10: 279-291. DOI: 10.3844/ajeassp.2017.279.291

Petrescu, R.V., R. Aversa, B. Akash, R. Bucinell and J. Corchado et al., 2017d. Inverse kinematics at the anthropomorphic robots, by a trigonometric method. Am. J. Eng. Applied Sci., 10: 394-411. DOI: 10.3844/ajeassp.2017.394.411

Petrescu, R.V., R. Aversa, B. Akash, R. Bucinell and J. Corchado et al., 2017e. Forces at internal combustion engines. Am. J. Eng. Applied Sci., 10: 382-393. DOI: 10.3844/ajeassp.2017.382.393

Petrescu, R.V., R. Aversa, B. Akash, R. Bucinell and J. Corchado et al., 2017f. Gears-Part I. Am. J. Eng. Applied Sci., 10: 457-472. DOI: 10.3844/ajeassp.2017.457.472

Petrescu, R.V., R. Aversa, B. Akash, R. Bucinell and J. Corchado et al., 2017g. Gears-part II. Am. J. Eng. Applied Sci., 10: 473-483.

DOI: 10.3844/ajeassp.2017.473.483

Petrescu, R.V., R. Aversa, B. Akash, R. Bucinell and J. Corchado et al., 2017h. Cam-gears forces, velocities, powers and efficiency. Am. J. Eng. Applied Sci., 10: 491-505. DOI: 10.3844/ajeassp.2017.491.505

Petrescu, R.V., R. Aversa, B. Akash, R. Bucinell and J. Corchado et al., 2017i. Dynamics of mechanisms with cams illustrated in the classical distribution. Am. J. Eng. Applied Sci., 10: 551-567. DOI: 10.3844/ajeassp.2017.551.567

Petrescu, R.V., R. Aversa, B. Akash, R. Bucinell and J. Corchado et al., 2017j. Testing by non-destructive control. Am. J. Eng. Applied Sci., 10: 568-583. DOI: 10.3844/ajeassp.2017.568.583

Petrescu, R.V., R. Aversa, B. Akash, R. Bucinell and J. Corchado et al., $2017 \mathrm{~m}$. Modern propulsions for aerospace-a review. J. Aircraft Spacecraft Technol., 1: 1-8. DOI: 10.3844/jastsp.2017.1.8 
Petrescu, R.V., R. Aversa, B. Akash, R. Bucinell and J. Corchado et al., 2017n. Modern propulsions for aerospace-part II. J. Aircraft Spacecraft Technol., 1: 9-17. DOI: 10.3844/jastsp.2017.9.17

Petrescu, R.V., R. Aversa, B. Akash, R. Bucinell and J. Corchado et al., 2017o. History of aviation-a short review. J. Aircraft Spacecraft Technol., 1: 30-49. DOI: 10.3844 jastsp.2017.30.49

Petrescu, R.V., R. Aversa, B. Akash, R. Bucinell and J. Corchado et al., 2017p. Lockheed martin-a short review. J. Aircraft Spacecraft Technol., 1: 50-68. DOI: 10.3844 jastsp.2017.50.68

Petrescu, R.V., R. Aversa, B. Akash, T.M. Abu-Lebdeh and A. Apicella et al., 2018d. Buses running on gas. Am. J. Eng. Applied Sci., 11: 186-201.

DOI: 10.3844/ajeassp.2018.186.201

Petrescu, R.V., R. Aversa, B. Akash, T.M. Abu-Lebdeh and A. Apicella et al., 2018e. Some aspects of the structure of planar mechanisms. Am. J. Eng. Applied Sci., 11: 245-259. DOI: 10.3844/ajeassp.2018.245.259

Petrescu, R.V., R. Aversa, S. Kozaitis, A. Apicella and F.I.T. Petrescu, 2017l. The quality of transport and environmental protection, part I. Am. J. Eng. Applied Sci., 10: 738-755. DOI: 10.3844/ajeassp.2017.738.755

Petrescu, RV., R. Aversa, T.M. Abu-Lebdeh, A. Apicella and F.I.T. Petrescu, 2018f. The forces of a simple carrier manipulator. Am. J. Eng. Applied Sci., 11: 260-272. DOI: 10.3844/ajeassp.2018.260.272

Petrescu, RV., R. Aversa, T.M. Abu-Lebdeh, A. Apicella and F.I.T. Petrescu, 2018g. The dynamics of the otto engine. Am. J. Eng. Applied Sci., 11: 273-287. DOI: 10.3844/ajeassp.2018.273.287

Petrescu, RV., R. Aversa, T.M. Abu-Lebdeh, A. Apicella and F.I.T. Petrescu, 2018h. NASA satellites help us to quickly detect forest fires. Am. J. Eng. Applied Sci., 11: 288-296. DOI: 10.3844/ajeassp.2018.288.296

Petrescu, RV., R. Aversa, T.M. Abu-Lebdeh, A. Apicella and F.I.T. Petrescu, 2018i. Kinematics of a mechanism with a triad. Am. J. Eng. Applied Sci., 11: 297-308. DOI: 10.3844/ajeassp.2018.297.308

Pisello, A.L., G. Pignatta, C. Piselli, V.L. Castaldo and F. Cotana, 2016. Investigating the dynamic thermal behavior of building envelope in summer conditions by means of in-field continuous monitoring. Am. J. Eng. Applied Sci., 9: 505-519. DOI: 10.3844/ajeassp.2016.505.519

Pourmahmoud, N., 2008. Rarefied gas flow modeling inside rotating circular cylinder. Am. J. Eng. Applied Sci., 1: 62-65. DOI: 10.3844/ajeassp.2008.62.65

Pravettoni, M., C.S.P. Lòpez and R.P. Kenny, 2016. Impact of the edges of a backside diffusive reflector on the external quantum efficiency of luminescent solar concentrators: Experimental and computational approach. Am. J. Eng. Applied Sci., 9: 53-63.

DOI: 10.3844 /ajeassp.2016.53.63
Qutbodin, K., 2010. Merging autopilot/flight control and navigation-flight management systems. Am. J. Eng. Applied Sci., 3: 629-630. DOI: 10.3844/ajeassp.2010.629.630

Rajbhandari, S., Z. Ghassemlooy and M. Angelova, 2011. The performance of a dual header pulse interval modulation in the presence of artificial light interferences in an indoor optical wireless communications channel with wavelet denoising. Am. J. Eng. Applied Sci., 4: 513-519. DOI: 10.3844/ajeassp.2011.513.519

Rajput, R.S., S. Pandey and S. Bhadauria, 2016. Correlation of biodiversity of algal genera with special reference to the waste water effluents from industries. Am. J. Eng. Applied Sci., 9: 1127-1133. DOI: 10.3844 /ajeassp.2016.1127.1133

Rajupillai, K., S. Palaniammal and K. Bommuraju, 2015. Computational intelligence and application of frame theory in communication systems. Am. J. Eng. Applied Sci., 8: 633-637. DOI: 10.3844/ajeassp.2015.633.637

Rama, G., D. Marinkovic and M. Zehn, 2016. Efficient co-rotational 3-node shell element. Am. J. Eng. Applied Sci., 9: 420-431.

DOI: 10.3844 /ajeassp.2016.420.431

Raptis, K.G., G.A. Papadopoulos, T.N. Costopoulos and A.D. Tsolakis, 2011. Experimental study of load sharing in roller-bearing contact by caustics and photoelasticity. Am. J. Eng. Applied Sci., 4: 294-300. DOI: 10.3844/ajeassp.2011.294.300

Rea, P. and E. Ottaviano, 2016. Analysis and mechanical design solutions for sit-to-stand assisting devices. Am. J. Eng. Applied Sci., 9: 1134-1143. DOI: 10.3844/ajeassp.2016.1134.1143

Rhode-Barbarigos, L., V. Charpentier, S. Adriaenssens and O. Baverel, 2015. Dialectic form finding of structurally integrated adaptive structures. Am. J. Eng. Applied Sci., 8: 443-454. DOI: 10.3844 /ajeassp.2015.443.454

Riccio, A., U. Caruso, A. Raimondo and A. Sellitto, 2016a. Robustness of XFEM method for the simulation of cracks propagation in fracture mechanics problems. Am. J. Eng. Applied Sci., 9: 599-610. DOI: 10.3844/ajeassp.2016.599.610

Riccio, A., R. Cristiano and S. Saputo, 2016b. A brief introduction to the bird strike numerical simulation. Am. J. Eng. Applied Sci., 9: 946-950. DOI: 10.3844/ajeassp.2016.946.950

Rich, F. and M.A. Badar, 2016. Statistical analysis of auto dilution $\mathrm{Vs}$ manual dilution process in inductively coupled plasma spectrometer tests. Am. J. Eng. Applied Sci., 9: 611-624. DOI: 10.3844/ajeassp.2016.611.624

Rohit, K. and S. Dixit, 2016. Mechanical properties of waste Biaxially Oriented Polypropylene Metallized Films (BOPP), LLDPE: LDPE films with sisal fibres. Am. J. Eng. Applied Sci., 9: 913-920. DOI: 10.3844/ajeassp.2016.913.920 
Rulkov, N.F., A.M. Hunt, P.N. Rulkov and A.G. Maksimov, 2016. Quantization of map-based neuronal model for embedded simulations of neurobiological networks in real-time. Am. J. Eng. Applied Sci., 9: 973-984. DOI: 10.3844/ajeassp.2016.973.984

Saikia, A. and N. Karak, 2016. Castor oil based epoxy/clay nanocomposite for advanced applications. Am. J. Eng. Applied Sci., 9: 31-40. DOI: 10.3844/ajeassp.2016.31.40

Sallami, A., N. Zanzouri and M. Ksouri, 2016. Robust diagnosis of a DC motor by bond graph approach. Am. J. Eng. Applied Sci., 9: 432-438. DOI: 10.3844/ajeassp.2016.432.438

Samantaray, K.S., S. Sahoo and C.S. Rout, 2016. Hydrothermal synthesis of CuWO4-reduced graphene oxide hybrids and supercapacitor application. Am. J. Eng. Applied Sci., 9: 584-590. DOI: 10.3844/ajeassp.2016.584.590

Semin and R.A Bakar, 2008. A technical review of compressed natural gas as an alternative fuel for internal combustion engines. Am. J. Eng. Applied Sci., 1: 302-311. DOI: 10.3844/ajeassp.2008.302.311

Semin, A.R.I. and R.A. Bakar, 2009a. Combustion temperature effect of diesel engine convert to compressed natural gas engine. Am. J. Eng. Applied Sci., 2: 212-216. DOI: 10.3844/ajeassp.2009.212.216

Semin, A.R.I. and R.A. Bakar, 2009b. Effect of diesel engine converted to sequential port injection compressed natural gas engine on the cylinder pressure vs crank angle in variation engine speeds. Am. J. Eng. Applied Sci., 2: 154-159. DOI: 10.3844/ajeassp.2009.154.159

Semin, S., A.R. Ismail and R.A. Bakar, 2009c. Diesel engine convert to port injection $\mathrm{CNG}$ engine using gaseous injector nozzle multi holes geometries improvement: A review. Am. J. Eng. Applied Sci., 2: 268-278. DOI: 10.3844/ajeassp.2009.268.278

Sepúlveda, J.A.M. 2016. Outlook of municipal solid waste in bogota (Colombia). Am. J. Eng. Applied Sci., 9: 477-483. DOI: 10.3844/ajeassp.2016.477.483

Serebrennikov, A., D. Serebrennikov and Z. Hakimov, 2016. Polyethylene pipeline bending stresses at an installation. Am. J. Eng. Applied Sci., 9: 350-355. DOI: 10.3844/ajeassp.2016.350.355

Shanmugam, K., 2016. Flow dynamic behavior of fish oil/silver nitrate solution in mini-channel, effect of alkane addition on flow pattern and interfacial tension. Am. J. Eng. Applied Sci., 9: 236-250.

DOI: 10.3844/ajeassp.2016.236.250

Shruti, 2016. Comparison in cover media under stegnography: Digital media by hide and seek approach. Am. J. Eng. Applied Sci., 9: 297-302. DOI: 10.3844/ajeassp.2016.297.302
Stavridou, N., E. Efthymiou and C.C. Baniotopoulos, 2015a. Welded connections of wind turbine towers under fatigue loading: Finite element analysis and comparative study. Am. J. Eng. Applied Sci., 8: 489-503. DOI: 10.3844/ajeassp.2015.489.503

Stavridou, N., E. Efthymiou and C.C. Baniotopoulos, $2015 \mathrm{~b}$. Verification of anchoring in foundations of wind turbine towers. Am. J. Eng. Applied Sci., 8: 717-729. DOI: 10.3844/ajeassp.2015.717.729

Suarez, L., T.M. Abu-Lebdeh, M. Picornell and S.A. Hamoush, 2016. Investigating the role of fly ash and silica fume in the cement hydration process. Am. J. Eng. Applied Sci., 9: 134-145. DOI: 10.3844 /ajeassp.2016.134.145

Syahrullah, O.I. and N. Sinaga, 2016. Optimization and prediction of motorcycle injection system performance with feed-forward back-propagation method Artificial Neural Network (ANN). Am. J. Eng. Applied Sci., 9: 222-235. DOI: 10.3844 /ajeassp.2016.222.235

Sylvester, O., I. Bibobra and O.N. Ogbon, 2015a. Well test and PTA for reservoir characterization of key properties. Am. J. Eng. Applied Sci., 8: 638-647. DOI: 10.3844/ajeassp.2015.638.647

Sylvester, O., I. Bibobra and O. Augustina, $2015 \mathrm{~b}$. Report on the evaluation of ugua J2 and J3 reservoir performance. Am. J. Eng. Applied Sci., 8: 678-688. DOI: 10.3844/ajeassp.2015.678.688

Taher, S.A., R. Hematti and M. Nemati, 2008. Comparison of different control strategies in GAbased optimized UPFC controller in electric power systems. Am. J. Eng. Applied Sci., 1: 45-52. DOI: 10.3844 /ajeassp.2008.45.52

Takeuchi, T., Y. Kinouchi, R. Matsui and T. Ogawa, 2015. Optimal arrangement of energy-dissipating members for seismic retrofitting of truss structures. Am. J. Eng. Applied Sci., 8: 455-464.

DOI: 10.3844 /ajeassp.2015.455.464

Theansuwan, W. and K. Triratanasirichai, 2011. The biodiesel production from roast thai sausage oil by transesterification reaction. Am. J. Eng. Applied Sci., 4: 130-132. DOI: 10.3844/ajeassp.2011.130.132

Thongwan, T., A. Kangrang and S. Homwuttiwong, 2011. An estimation of rainfall using fuzzy setgenetic algorithms model. Am. J. Eng. Applied Sci., 4: 77-81. DOI: 10.3844/ajeassp.2011.77.81

Tourab, W., A. Babouri and M. Nemamcha, 2011. Experimental study of electromagnetic environment in the vicinity of high voltage lines. Am. J. Eng. Applied Sci., 4: 209-213. DOI: 10.3844/ajeassp.2011.209.213

Tsolakis, A.D. and K.G. Raptis, 2011. Comparison of maximum gear-tooth operating bending stresses derived from niemann's analytical procedure and the finite element method. Am. J. Eng. Applied Sci., 4: 350-354. DOI: 10.3844/ajeassp.2011.350.354 
Vernardos, S.M. and C.J. Gantes, 2015. Cross-section optimization of sandwich-type cylindrical wind turbine towers. Am. J. Eng. Applied Sci., 8: 471-480. DOI: 10.3844/ajeassp.2015.471.480

Wang, J. and Y. Yagi, 2016. Fragment-based visual tracking with multiple representations. Am. J. Eng. Applied Sci., 9: 187-194. DOI: 10.3844 ajeassp.2016.187.194

Wang, L., G. Wang and C.A. Alexander, 2015. Confluences among big data, finite element analysis and high-performance computing. Am. J. Eng. Applied Sci., 8: 767-774. DOI: 10.3844/ajeassp.2015.767.774

Wang, L., T. Liu, Y. Zhang and X. Yuan, 2016. A methodology for continuous evaluation of cloud resiliency. Am. J. Eng. Applied Sci., 9: 264-273. DOI: 10.3844/ajeassp.2016.264.273

Waters, C., S. Ajinola and M. Salih, 2016. Dissolution sintering technique to create porous copper with sodium chloride using polyvinyl alcohol solution through powder metallurgy. Am. J. Eng. Applied Sci., 9: 155-165. DOI: 10.3844/ajeassp.2016.155.165

Wessels, L. and H. Raad, 2016. Recent advances in point of care diagnostic tools: A review. Am. J. Eng. Applied Sci., 9: 1088-1095. DOI: 10.3844/ajeassp.2016.1088.1095

Yan, C., F. Gao and W. Guo, 2009. Coordinated kinematic modeling for motion planning of heavyduty manipulators in an integrated open-die forging center. J. Eng. Manufacture, 223: 1299-1313.

Yang, M.F. and Y. Lin, 2015. Process is unreliable and quantity discounts supply chain integration inventory model. Am. J. Eng. Applied Sci., 8: 602-610. DOI: 10.3844/ajeassp.2015.602.610

Yeargin, R., R. Ramey and C. Waters, 2016. Porosity analysis in porous brass using dual approaches. Am. J. Eng. Applied Sci., 9: 91-97. DOI: 10.3844/ajeassp.2016.91.97
You, M., X. Huang, M. Lin, Q. Tong and X. Li et al., 2016. Preparation of LiCoMnO4 assisted by hydrothermal approach and its electrochemical performance. Am. J. Eng. Applied Sci., 9: 396-405. DOI: 10.3844/ajeassp.2016.396.405

Zeferino, R.S., J.A.R. Ramón, E.D. Anda Reyes, R.S. González and U. Pal, 2016. Large scale synthesis of $\mathrm{ZnO}$ nanostructures of different morphologies through solvent-free mechanochemical synthesis and their application in photocatalytic dye degradation. Am. J. Eng. Applied Sci., 9: 41-52. DOI: 10.3844/ajeassp.2016.41.52

Zhao, B., 2013. Identification of multi-cracks in the gate rotor shaft based on the wavelet finite element method. Am. J. Eng. Applied Sci., 6: 309-319. DOI: 10.3844/ajeassp.2013.309.319

Zheng, H. and S. Li, 2016. Fast and robust maximum power point tracking for solar photovoltaic systems. Am. J. Eng. Applied Sci., 9: 755-769. DOI: 10.3844/ajeassp.2016.755.769

Zotos, I.S. and T.N. Costopoulos, 2009. On the use of rolling element bearings' models in precision maintenance. Am. J. Eng. Applied Sci., 2: 344-352. DOI: 10.3844 /ajeassp.2009.344.352

Zulkifli, R., K. Sopian, S. Abdullah and MS. Takriff, 2008. Effect of Pulsating Circular Hot Air Jet Frequencies on Local and Average Nusselt Number, Am. J. Eng. Applied Sci., 1: 57-61. DOI: 10.3844/ajeassp.2008.57.61

Zulkifli, R., K. Sopian, S. Abdullah and M.S. Takriff, 2009. Experimental study of flow structures of circular pulsating air jet. Am. J. Eng. Applied Sci., 2: 171-175. DOI: 10.3844/ajeassp.2009.171.175

Zurfi, A. and J. Zhang, 2016a. Model Identification and Wall-Plug Efficiency Measurement of White LED Modules. Am. J. Eng. Applied Sci., 9: 412-419. DOI: 10.3844 /ajeassp.2016.412.419

Zurfi, A. and J. Zhang, 2016b. Exploitation of battery energy storage in load frequency control-a literature survey. Am. J. Eng. Applied Sci., 9: 1173-1188. DOI: 10.3844 /ajeassp.2016.1173.1188 